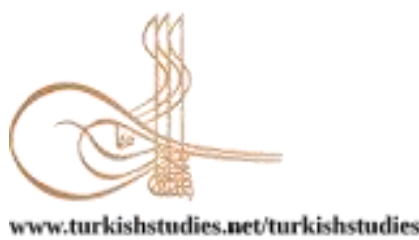

Turkish Studies

\title{
Pandemi Sürecinde Eğitim Fakültesi Öğrencilerinin Çevrimiçi Öğrenme Hazır Bulunuşluk ve E-öğrenme Ortamlarına Yönelik Motivasyon Düzeyleri
}

\author{
Online Learning Readiness and E-learning Environments Motivation Levels of the Education \\ Faculty Students in the Pandemic Outbreak
}

\author{
Mihrap Baygeldi * - Gülcan Öztürk** - Filiz Tuba Dikkartın Övez***
}

\begin{abstract}
Evaluating the social and educational effects of the coronavirus epidemic, which is declared as pandemic outbreak, has been an important issue not only in the context of our country but also in the World. In this process, where social life has been changing rapidly, analysing the problems, opportunities and readiness of the students who have not been taught face-to-face has also been a vital issue in terms of taking some precautions for the pandemic outbreak in the future. In this regard, the aim of the study is to determine the online learning readiness and e-learning environments motivation levels of the education faculty students whose face-to-face education have been interrupted in the pandemic outbreak and therefore, whose education has been transformed from face-to face to distance education. Besides, this study examines the relationship between the online learning readiness and e-learning environments motivation levels of the students. The exploratory correlational research model and the convenience sampling method is used in the study. The sample of the study consists of 221 students from an education faculty in the west of Turkey in the spring semester of 2019-2020 academic year. In the study, the information form composed by the researchers, the Online Learning Readiness Scale, and the E-Learning Environments Motivation Questionnaire are used to collect the data. During the study, an application for the approval of the ethics committee was made to Balikesir University and the ethics committee permission document dated 24.12.2020 and numbered E-19928322-302.08.01-1681 that there was no contradiction to research ethics was approved. An online form is generated for the scales, and the data are collected by transmitting the scales to the participants. The t-test for the independent samples is performed to determine whether the online learning readiness scores and e-learning environments motivation scores of the students differ according to their gender, having a computer, having internet access, participating in an online and an offline course by using the statistical analysis package program. The one-way analysis of
\end{abstract}

\footnotetext{
* Öğretmen, Milli Eğitim Bakanlığı, Zonguldak, Kilimli, Işıkveren Ortaokulu

Teacher, Ministry of National Education, Zonguldak, Kilimli, Işıkveren Middle School ORCID 0000-0002-5794-100X

mihrap225@gmail.com

** Dr. Öğr. Üyesi, Balıkesir Üniversitesi, Necatibey Eğitim Fakültesi, Bilgisayar ve Öğretim Teknolojileri Eğitimi Bölümü Assist. Prof. Dr., Ballkesir University, Necatibey Faculty of Education, Department of Computer Education and Instructional Technology

ORCID 0000-0003-4399-1329

ozturkg@balikesir.edu.tr

**** Doç. Dr., Balıkesir Üniversitesi, Necatibey Eğitim Fakültesi, Matematik ve Fen Bilimleri Eğitimi Bölümü Assoc. Prof. Dr., Ballkesir University, Necatibey Faculty of Education, Department of Mathematics and Science Education ORCID 0000-0003-2646-5327

tdikkartin@balikesir.edu.tr

Cite as/ Atıf: Baygeldi, M., Öztürk G, \& Dikkartın Övez, F. T. (2021). Pandemi sürecinde eğitim fakültesi öğrencilerinin çevrimiçi öğrenme hazır bulunuşluk ve e-öğrenme ortamlarına yönelik motivasyon düzeyleri. Turkish Studies, 16(1), 285-311. https://dx.doi.org/10.7827/TurkishStudies.44485

Received/Geliş: 24 June/Haziran 2020

Accepted/Kabul: 20 Şubat/February 2021

Checked by plagiarism software

Published/Yayın: 25 Şubat February 2021

CC BY-NC 4.0
} 
variance for the independent samples is carried out to determine whether they differ according to grade level, computer usage time, internet usage time, and time spent in the distance education. The correlation coefficient is calculated to determine whether the online learning readiness scores and e-learning environments motivation scores of the students are related. The result of the research indicates that the online learning readiness scores of the students are high, their e-learning environments motivation scores are not very low and the online learning readiness scores is positively correlated with the e-learning environments motivation scores.

Structured Abstract: Introduction and aim of study: The spread of coronavirus [COVID-19] around the world in 2020 has paved the way the suspension of the formal education activities in Turkey in March (Yüksekögretim Kurulu [YÖK], 2020). Due to the effects of pandemic outbreak, the education of the students of all grades have still been carried out online. Particularly, at the universities, this transition process has shown differences because of their technical infrastructure. Since this sudden crisis is not only a short-term problem, but also it might have permanent and long lasting consequences, particularly on the affected societies by increasing the inequalities, which are presumably anticipated (Nguyen \& Huynh, 2020). The limited number of academic studies on the problems that could be faced in the rapid change in education during the pandemic outbreak has made it difficult to foresee the problems that might arise. For this reason, the results of the studies conducted in a limited time to investigate all possible difficulties that many students and teachers may encounter could contribute to overcoming the crisis in the education in the long term. In this process, where social life has been changing rapidly, analysing the problems, opportunities and readiness of the students who have not been taught face-to-face has also been a vital issue in terms of taking some precautions for the pandemic outbreak in the future. In this regard, the aim of the study is to determine the online learning readiness and e-learning environments motivation levels of the education faculty students whose education have been interrupted in the pandemic outbreak and whose education has been transformed from face-to-face education to distance education. Besides, this study examines the relationship between the online learning readiness and e-learning environments motivation levels of the students. Thus, this study examines the following research questions:

1- What levels of the online learning readiness and e-learning environments motivation of the students are in the pandemic outbreak?

2- Do the online learning readiness and e-learning environments motivation levels of the students differ according to various variables (gender, grade level, having a computer, having internet access, computer usage time, internet usage time, participating in an online and an offline course, time spent in the distance education) in the pandemic outbreak?

3- Is there a significant relationship between the online learning readiness and e-learning environments motivation levels o the students in the pandemic outbreak?

Method: Research Model: Exploratory correlational research model is used in the study. The exploratory correlational research model is used to try to understand an important event by analysing the relationships between the variables (Büyüköztürk et al., 2009). The demographic variables (gender, grade level, having a computer, having internet access, computer usage time, internet usage time, participating in an online and an offline course, time spent in the distance education) are used as independent variables. The dependent variables are the level of the online learning readiness and the level of e-learning environments motivation.

Sample: The convenience sampling method is used in the study. The sample of the study consists of 221 students from an education faculty in the west of Turkey in the spring semester of the 2019-2020 academic year.

Data Collection Tools: The information form composed by the researchers, the Online Learning Readiness Scale adapted to Turkish by Yurdugül and Alsancak Sirakaya (2013), and the E-Learning Environments Motivation Questionnaire adapted to Turkish by Y1ldirım (2012) are used to collect the data in the study. During the study, an application for the approval of the ethics committee was made to Balıkesir University and the ethics committee permission document dated 24.12.2020 and numbered E-19928322302.08.01-1681 that there was no contradiction to research ethics was approved. An online form is generated for the scales, and the data are collected by transmitting the scales to the participants. In the information form, the questions regarding the demographic information of the students (gender, grade level, having a computer, having internet access, computer usage time, internet usage time, participating in an online and an offline course, time spent in the distance education) are administered. 
Data Analysis: The statistical analysis package program (IBM SPSS Statistics 24) is used to analyze the data collected in the study. The descriptive statistics are used in order to determine the distribution of the online learning readiness and e-learning environments motivation scores. The skewness and kurtosis values of the data according to independent variables (gender, grade level, having a computer, having internet access, computer usage time, internet usage time, participating in an online and an offline course, time spent in the distance education) are examined. Since the data demonstrates normal distribution according to skewness and kurtosis values, the t-test for the independent samples is performed to determine whether the online learning readiness scores and e-learning environments motivation scores of the students differ according to their gender, having a computer, having internet access, participating in an online and an offline course. The one-way analysis of variance for the independent samples is carried out to determine whether they differ according to grade level, computer usage time, internet usage time, and time spent in the distance education. The correlation coefficient is calculated to determine whether the online learning readiness scores and e-learning environments motivation scores of the students are related.

Results and discussion: The mean of the online learning readiness scores of the students is $\bar{X}=3.67$. This score can be interpreted as the high level of the online learning readiness. Similarly, the e-learning environments motivation levels of the students can be interpreted not too low because the mean of their scores is $\bar{X}=3.12$. The t-test for the independent samples is performed to determine whether the online learning readiness scores and e-learning environments motivation scores of the students differ according to their gender, having a computer, having internet access, participating in an online and an offline course. According to the ttest results, the online learning readiness scores do not differ significantly according to all these variables, while the e-learning environments motivation scores demonstrates a significant difference according to having a computer and participating in an online course. The e-learning environments motivation scores do not differ significantly according to other variables. The one-way analysis of variance for the independent samples is carried out to determine whether the scores differ according to grade level, computer usage time, internet usage time, and time spent in the distance education. The result of the one-way analysis of variance indicates that there is a significant difference in the mean of both the online learning readiness scores and e-learning environments motivation scores according to computer usage time and time spent in the distance education. The Pearson correlation coefficient is calculated to determine whether the online learning readiness scores and e-learning environments motivation scores of the students are related. The scores are found to be moderately positive and significantly related, $\mathrm{r}=.487, \mathrm{p}<.05$. Considering the determination coefficient $\left(\mathrm{r}^{2}=.2371\right)$, that $24 \%$ of the change in the online learning readiness is due to the level of the e-learning environments motivation can be said. Or that $24 \%$ of the level of the e-learning environments motivation is caused by the online learning readiness can be stated (Büyüköztürk, 2020).

Conclusions and Recommendations: The result of the research indicates that the online learning readiness scores of the students are high, that their e-learning environments motivation scores are not very low and that the online learning readiness scores is positively correlated with the e-learning environments motivation scores. The study can be repeated in different students groups by different measurement tools, or by qualitative research methods. The sample of the study consists of education faculty students in the pandemic outbreak. The study can be conducted with different faculty students or students studying at different grade levels, and the relationship can be examined. There is no evidence in the literature regarding the effect of the variables that is time spent in the distance education and computer usage time on the online learning readiness levels. In addition, there is no similar study in the literature examining the effect of the variables that is having a computer and internet access on the e-learning environments motivation levels. In different studies, the relationship between different variables and the online readiness and e-learning environments motivation of the students can be examined. While developing the contents of e-learning environments, determining factors such as readiness and motivation in advance may be beneficial to students' concentration and effectiveness in the e-learning process.

Keywords: Online learning, e-learning, readiness, motivation, COVID-19

Öz: Pandemi olarak ilan edilen korona virüs salgınının sosyal ve eğitimsel etkilerinin değerlendirilmesi sadece ülkemiz bağlamında değil Dünya bağlamında da önemli bir konu olmuştur. Sosyal hayatın hızla değiştiği bu süreçte yüz yüze öğrenim göremeyen öğrencilerin karşılaştıkları sorunların, imkânların ve hazır bulunuşluklarının incelenerek analiz edilmesi, gelecekte ortaya çıkacak pandemiler için önlemler alınması 
açısından çok önemlidir. Bu doğrultuda çalışmanın amacı, pandemi sürecinde yüz yüze eğitimleri kesintiye uğrayan ve uzaktan eğitime geçiş yapan eğitim fakültesi öğrencilerinin çevrimiçi öğrenme hazır bulunuşluk ve e-öğrenme ortamlarına yönelik motivasyon düzeylerini belirlemek ve bunlar arasındaki ilişkiyi incelemektir. Çalışmada, keşfedici korelasyonel araştırma modeli ve uygun örnekleme yöntemi kullanılmıştır. Örneklem, 2019-2020 eğitim-öğretim yılı bahar yarıyılında Türkiye'nin batısında bulunan bir eğitim fakültesinde öğrenim gören 221 öğrenciden oluşturmaktadır. Verilerin toplanması için araştırmacılar tarafindan oluşturulan bilgi formu, Çevrimiçi Öğrenme Hazır Bulunuşluluk Ölçeği ve E-Öğrenme Ortamlarına Yönelik Motivasyon Anketi kullanılmıştır. Çalışma esnasında etik kurul onayı için Balıkesir Üniversitesi'ne başvurulmuş ve araştırma etiğine aykırı bir durum olmadığı 24.12.2020 tarih ve E-19928322-302.08.01-1681 sayılı etik kurul izin belgesi ile onaylanmıştır. Kullanılan ölçekler için online form oluşturulmuş ve katılımcılara iletilerek veriler toplanmıştır. Öğrencilerin çevrimiçi öğrenme hazır bulunuşluk ve e-öğrenme ortamlarına yönelik motivasyon puanlarının, cinsiyet, bilgisayara sahip olma, internet erişimine sahip olma, çevrimiçi ve çevrimdışı derse katılma durumu değişkenlerine göre farklılaşıp farklılaşmadığını belirlemek için istatistiksel analiz paket programı kullanılarak ilişkisiz örneklemler için t-testi kullanılmıştır. Puanların sınıf düzeyi, bilgisayar kullanma süresi, internet kullanma süresi ve uzaktan eğitim sisteminde geçirilen süre değişkenlerine göre farklılaşıp farklılaşmadığını belirlemek için ilişkisiz örneklemler için tek yönlü varyans analizi yapılmıştır. Öğrencilerin çevrimiçi öğrenme hazır bulunuşluk ve e-öğrenme ortamlarına yönelik motivasyon puanlarının ilişkili olup olmadığını belirlemek için korelasyon katsayısı hesaplanmıştır. Araştırma sonuçları, katılımcıların çevrimiçi öğrenme hazır bulunuşluk puanlarının yüksek düzeyde olduğunu; e-öğrenme ortamlarına yönelik motivasyon puanlarının çok düşük düzeyde olmadığını ve çevrimiçi öğrenme hazır bulunuşluklarının eöğrenme ortamlarına yönelik motivasyonlarıyla pozitif yönlü orta düzeyde ilişkili olduğunu göstermiştir.

Anahtar Kelimeler: Çevrimiçi öğrenme, e-öğrenme, hazır bulunuşluk, motivasyon, COVID-19

\section{Giriş}

Eğitim her çağda insan hayatının ayrılmaz bir parçası olmuştur ve eğitimin niteliğinin geliştirilmesi için insanoğlu sürekli çaba göstermiştir (Bertiz, 2018; Yurdakul, 2005). Bilişim teknolojilerindeki gelişim hayatın her alanında olduğu gibi eğitim alanında da yerini almış ve bilişim teknolojileri eğitimde etkili bir şekilde kullanılmaya başlanmıştır (Usta, 2011a). Bilişim teknolojilerindeki gelişim, eğitimin niteliğinin artırılmasında önemli bir rol oynamış ve eğitim alanında değişimi zorunlu kılmıştır (Akıncı ve Seferoğlu, 2010). Gelişen teknolojilerle bilgiye erişimin kolaylaşması, eğitimin yaygınlaşmasına, erişilen bilginin niteliğinin değişmesine ve eğitimde ihtiyaçların farklılaşmasına neden olmuştur. Bu nedenle eğitimde teknoloji entegrasyonu kaçınılmaz bir zorunluluk haline gelmiştir. Günümüzde eğitimde teknoloji entegrasyonunun en yaygın kullanılan teknolojik elemanı internet olmuştur. Çünkü eğitim sürecindeki mevcut sorunlar veya zorluklar bilişim teknolojileriyle ve ilerleyen süreçte internetle aşılmaya çalışılmıştır (Enfiyeci, 2019). Eğitim sürecinde öğrenci ile öğretmen arasındaki fiziksel engeller, yaş, çalışıyor olma durumu, aradaki mesafe gibi sınırlılıklar nedeniyle eğitimin niteliğinin geliştirilmesinde ortaya çıkan sorunlar uzaktan eğitim kavramının ortaya çıkmasına zemin hazırlamıştır (Bertiz, 2018). Günümüzde ise yaşanan korona virüs [COVID-19] pandemi sürecinde uzaktan eğitim bir zorunluluk halini almıştır (Yükseköğretim Kurulu [YÖK], 2020).

19. yüzyılda kurumsal olarak uygulanmaya başlanan uzaktan eğitim 20. yüzyılda internetle birlikte daha da yaygın hale gelmiştir (Akdemir, 2011; Karataş ve Üstündağ, 2008). İnternetin gelişmesiyle birlikte uzaktan eğitimle ilgili yeni kavramlar ortaya çıkmıştır. Alanyazında, çevrimiçi öğrenme, e-öğrenme, bilgisayar temelli öğrenme, eş zamanlı öğrenme, eş zamansız öğrenme, bilgisayar destekli uzaktan eğitim, web tabanlı öğrenme kavramlarıyla sıklıkla karşılaşılmaktadır (Aydın, 2002). Bu kavramlar, birbirlerinden farklı uygulamaları içermelerine karşın genel olarak öğrenme-öğretme sürecinde bilgisayar ağlarından yararlanılan uygulamaları ifade etmektedir ve uzmanlar çalışma alanlarına göre bu kavramlardan birini seçip kullanmaktadırlar (Gümüş, 2007).

Uzaktan eğitim, öğrenci, öğretmen ve öğrenme kaynaklarının birbirleri arasındaki sınırlılıkları yok etmeye çalışan ve bu amaç için var olan teknolojileri faydacı yaklaşımla kullanmaya 
çalışan bir disiplindir (Bozkurt, 2017). Uzaktan eğitim, kaynak ve alıcıların öğrenme-öğretme sürecinin büyük bir çoğunluğunda birbirlerinden farklı ortamlarda bulundukları, bulunduğu konum, yaş, öğrenme amacı vb. sebeplerle öğrenci grubuna esneklik, bireysellik, bağımsızlık sağlayan ve öğrenme-öğretme sürecinde yazılı basılı materyallerin yanı sıra işitsel, görsel-işitsel teknolojilerin de kullanıldığı, kaynak ile alıcı arasındaki etkileşimin televizyon veya bilgisayar aracılığı ile gerçekleştirildiği, sistematik ve planlı eğitim teknolojisi uygulaması olarak tanımlanmıştır (Uşun, 2006). Avrupa Birliği Uzaktan Eğitim Harekât Planında uzaktan eğitim sistemi, "eğitim faaliyetlerinin kalitesini artırmak için internet ve çoklu ortam teknolojileri kullanılarak kaynaklara erişim, bilgi değişimi ve iş birliğinin sağlanması" olarak tanımlanmıştır (Commission of the European Communities, 2001; Düzakın ve Yalçınkaya, 2008). İşman (2005), uzaktan eğitimi farklı ortamlardaki öğrenci ve öğretmenlerin iletişim teknolojileri ve e-posta hizmetlerini kullanarak öğrenme-öğretme etkinliklerini gerçekleştirdikleri eğitim sistemi modeli olarak tanımlamıştır. Koçdar (2011), uzaktan eğitimin mesleki becerilerin geliştirilmesi, yüz yüze öğretime katılamayan bireylere öğretim imkânı tanınması, mevcut eğitsel kaynakların niteliğinin artırılması, öğrenme fırsatlarına daha çok erişim sağlayabilme, eğitim kapasitesinin genişletilmesi amacıyla kullanılmaya başlandığını belirtmiştir.

Uzaktan eğitim eş zamanlı (senkron) yürütülebildiği gibi eş zamansız (asenkron) olarak da yürütülebilir (Yıldız, 2016). Eş zamanlı eğitim, aynı ortamı paylaşmayan kullanıcıların (öğretmen ve öğrenci) eş zamanlı olarak bir araya gelmesi, etkileşimli bir öğretim sürecinin gerçekleştirmeleridir. Eş zamansız eğitim ise yine farklı ortamlarda bulunan öğretmen ve öğrencilerin kendi öğrenme hızlarına göre ders içeriklerine istedikleri zaman ulaşabildikleri bir öğretim sürecidir (Erfidan, 2019; Özkaraca, 2005).

Uzaktan eğitim, yüz yüze öğretimden farklı olduğu için öğrencilerde olması beklenen birtakım özellikler vardır ve bunların başında da yüksek motivasyon gelmektedir (Kaya, 2002). Öğrenme sürecinin etkili bir şekilde devamlılığı için motivasyon önemli bir unsurdur ve hangi çeşit öğrenme ortamı olursa olsun motivasyon, öğrenmenin en önemli bileşenlerinden birisidir (Ergül, 2006; Seven ve Engin, 2008). Motivasyon, kişileri bir davranış1 yapmaya yönelten, onlara enerji veren ve onların içinde oluşan bilişsel, duyuşsal ve fizyolojik boyutları güçlendirme durumu olarak tanımlanmaktadır (Fidan, 1997'den aktaran Ergül, 2006). Motivasyon kavramı aynı zamanda güdüleme olarak da ifade edilmektedir ve güdüleme, güdülemek işi, motivasyon olarak tanımlanmaktadır (Türk Dil Kurumu [TDK], 2008). Geleneksel öğretim sürecinde olduğu gibi uzaktan eğitim sürecinde de motivasyon öğrenme sürecinin önemli bir parçasıdır (Khan, 2009).

Günümüzde uzaktan eğitimde öğrenme süreci çoğunlukla sanal bir ortamda gerçekleşmektedir. Öğrenmenin gerçekleştiği, öğrenci ve öğretmenin bir araya geldiği, aralarındaki etkileşimin sağlandığı bu ortama çevrimiçi ortam denilmektedir (Çalışkan, 2019; Enfiyeci, 2019). Çevrimiçi ortamlarda öğrenci geleneksel sınıfın birliktelik duygusundan uzak kalmakta, daha bireysel ve bağımsız çalışmalar yapmakta ve öğrenmenin etkililiği için motivasyon daha gerekli hale gelmektedir (Enfiyeci, 2019).

İnternetin gelişmesi ve yaygınlaşması, uzaktan eğitim kullanan bireylerin bilgiye ulaşmalarında büyük kolaylık sağlamıştır (Erfidan, 2019). Dolayısıyla günümüzde uygulanan uzaktan eğitim, e-öğrenme biçiminde yaygınlaşmaya başlamıştır (Gökdaş ve Kayri. 2005). Gülbahar (2012), öğretimin elektronik ortamlarda yapılması veya bilgi ve becerilerin bilişim teknolojileri ile aktarılmasını e-öğrenme olarak tanımlamıştır. E-öğrenme, bilgisayar ve iletişim teknolojileri kullanılarak öğretim süresi içerisinde öğretmen ve öğrencinin fiziksel olarak aynı ortamda olmasını gerektirmeyen öğretim yöntemi olarak da tanımlanmıştır (Altıparmak ve diğerleri, 2011). Çevrimiçi öğrenme (online learning) ve e-öğrenme (e-learning) kavramları aynı anlamda kullanılmaktadır (Gümüş, 2007; Sakal, 2017). E-öğrenme kavramı bilgisayar destekli öğrenme ortamına bilgisayar ağlarının da girmesi sonucunda ortaya çıkan bir kavramdır (Gümüş, 2007; Özcan, 2019). E-öğrenme, 
öğrenme etkinliklerinin internet ortamında veya benzer platformlarda eş zamanlı veya eş zamansız olarak ve her öğrencinin kendi öğrenme hızında yürütüldügü etkinlikler bütünü olarak tanımlanmıştır (Kör ve diğerleri, 2013). Çevrimiçi öğrenme veya e-öğrenme, herhangi bir ek yazılım ve öğrenme kaynağına ihtiyaç duymaksızın bir tarayıcı veya akıllı telefon uygulaması üzerinden gerçekleşen öğrenme türü olarak da tanımlanmıştır (Horton, 2006). İnternet teknolojileri kullanılarak elektronik ortamda yürütülen uzaktan eğitim, çevrimiçi öğrenme veya e-öğrenme olarak tanımlanabilir (Gümüş, 2007; Mutlu ve diğerleri, 2004).

Çevrimiçi öğrenme ortamı, kullanıcılar arası her türlü etkileşimin internet ağı aracıllı̆ııla eş zamanlı veya eş zamansız olarak sağlandığı, sınavlar, ders içerikleri, ödevler ve çeşitli öğretim etkinliklerinin yer aldığı web tabanlı platformdur (Yıldırım, 2012). Çevrimiçi öğrenmenin öğrencilere sağladığı birçok avantaj vardır. Bunların başında kolaylık ve esneklik gelse de öğrencilerin bu avantajlardan yararlanması için çevrimiçi öğrenme hazır bulunuşluğuna sahip olmaları gerekir (Alsancak Sırakaya ve Yurdugül, 2016; Usta, 2011b). Türkçe alanyazında hazır bulunuşluk ifadesi hazır bulunuşluluk olarak da kullanılmaktadır (Canbulat ve Kırıktaş, 2016; Süer, 2010; Yurdugül ve Alsancak Sırakaya, 2013). Hazır bulunuşluk bir davranış1 yapabilmek için sosyal, bilişsel, duyuşsal ve psikomotor yönlerden hazır olma durumudur (Yenilmez ve Kakmacı, 2008). Çevrimiçi öğrenme hazır bulunuşluğu, "çevrimiçi öğrenme deneyim ve eylemleri için zihinsel ve fiziksel olarak hazırlıklı olma" olarak tanımlamıştır (Borotis ve Poulymenakou, 2004). Farklı bir tanıma göre çevrimiçi öğrenme hazır bulunuşluğu, öğrencinin çevrimiçi ortamda öğrenme için gereken ön koşul bilgi, inanç ve becerilere sahip olmasını ifade etmektedir (Çakır ve Horzum, 2015; Warner ve diğerleri, 1998). Başka bir tanıma göre ise internet gibi e-kaynakların kullanımıyla kolaylaştırılan fırsatları takip etme kapasitesi çevrimiçi öğrenme hazır bulunuşluğudur (Maugis ve diğerleri, 2003; Yurdugül ve Alsancak Sırakaya, 2013). Çevrimiçi öğrenme hazır bulunuşluğu, çevrimiçi ortamda öğrencinin öğrenmesi için büyük önem taşımaktadır. Yapılan araştırmalar öğrencilerin öğretime devam etme, başarı ve tutumlarının hazır bulunuşluktan etkilendiğini ortaya koymaktadır (Demir Kaymak ve Horzum, 2013; Sop, 2016; Ünal ve Özdemir, 2008). Öğrencilerin yeterli hazır bulunuşluğa sahip olmaları, başarılarını ve tutumlarını etkilediği gibi motivasyonlarını da etkilemektedir (Korkmaz ve diğerleri, 2015).

Çevrimiçi öğrenme hazır bulunuşluk düzeyleri konusunda çeşitli çalışmalar yapılmıştır (Alsancak Sirakaya ve Yurdugül, 2016; Çatana Kuleli, 2018; Hung ve diğerleri, 2010; Ibrahim ve diğerleri, 2002; Sakal, 2017; Tubaishat ve Lansari, 2011; Yakın ve Tınmaz, 2013). Çevrimiçi öğrenme ortamında öğrenim gören lisans öğrencilerinin cinsiyet, yaş, bilgisayara sahip olma ve internet erişimine sahip olma durumu değişkenleri ile çevrimiçi öğrenme hazır bulunuşluğu arasında anlamlı ilişki bulunmadığ (Ibrahim ve diğerleri, 2002) görülmüştür. Farklı lisans dallarında öğrenim gören 1051 öğrencinin katıldığı çalışmada erkek ve kadınların çevrimiçi öğrenme hazır bulunuşluğu açısından bütün boyutlarda benzer seviyede oldukları ancak motivasyon boyutunda, son sinıf lisans öğrencilerinin birinci ve ikinci sınıf öğrencilerine göre daha yüksek seviyede oldukları görülmüştür (Hung ve diğerleri, 2010). Ayrıca lisans öğrencilerinin kendilerini e-öğrenmeye hazır hissettikleri ve e-öğrenmenin, öğrenmeyi kolaylaştırdığını düşündükleri (Tubaishat ve Lansari, 2011); öğretmen adaylarının kendilerini e-öğrenme için gerekli yeterliklere sahip gördükleri, hazır bulunuşluk düzeylerinin cinsiyetlerine göre anlamlı bir farklılık göstermediği (Yakın ve Tınmaz, 2013); lisans öğrencilerinin çevrimiçi öğrenme hazır bulunuşluk düzeylerinde bölüm ve cinsiyet değişkenlerine göre anlamlı farklılık olduğu (Sakal, 2017) belirlenmiştir. Bunun yanında 412 öğretmen adayının katıldığı bir çalışmada ise çevrimiçi öğrenme hazır bulunuşluğunun bilgisayar/internet özyeterliği ve özgüdümlü öğrenme alt boyutlarında cinsiyet değişkenine göre, bilgisayar/internet özyeterliği alt boyutunda sınıf düzeyine ve öğrenim görülen bölüme göre anlamlı farklılık olduğu sonuçları elde edilmiştir (Alsancak Sırakaya ve Yurdugül, 2016). Benzer şekilde Çatana Kuleli (2018) tarafından yapılan çalışmada, öğretmen adaylarının çevrimiçi öğrenme hazır bulunuşluk düzeylerinde haftalık internet kullanma süresi değişkenine göre anlamlı bir farklılık görülmezken, öğrenim görülen bölüm 
değişkenine göre bilgisayar/internet özyeterliği ve öğrenci kontrolü boyutunda, sınıf düzeyi değişkenine göre çevrimiçi iletişim özyeterliği, özgüdümlü öğrenme ve bilgisayar/internet özyeterliği boyutunda, cinsiyet değişkenine göre özgüdümlü öğrenme ve çevrimiçi iletişim boyutunda, daha önce çevrimiçi veya çevrimdışı derse katılma durumu değişkenine göre ise bilgisayar/internet özyeterliği, öğrenci kontrolü, öğrenci motivasyonu ve çevrimiçi iletişim özyeterliği boyutlarında anlamlı farkl1l1klar görülmüştür.

Alanyazında uzaktan eğitim ve motivasyon konulu çalışmalar da yer almaktadır (Akandere ve diğerleri, 2010; Azizoğlu ve Çetin, 2009; Demir, 2008; Kaya, 2013; Özan ve diğerleri, 2010; Seven ve Engin, 2008; Verhagen ve diğerleri, 2012). Uzaktan eğitim alan lisans öğrencilerinin güdülenme düzeylerinde cinsiyetlerine göre anlamlı farkl1lı olmadığı; yaş, bölüm, sınıf ve mezun oldukları lise türü değişkenlerine göre anlamlı farklılık olduğu görülmüsstür (Demir, 2008). Sanal ortamlardaki içsel ve dışsal motivasyonu artırmaya yönelik bir model geliştirilmesi üzerine yapılan bir çalışmada, sanal ortamın kolay kullanım, görsel çekicilik, ekonomik değer, hayal kurma ve tutum bileşenlerinin içsel ve dışsal motivasyonu etkilediği sonucuna ulaşılmıştır (Verhagen ve diğerleri, 2012). Ayrıca uzaktan eğitimde öğrencilerin motivasyonları, öğrencilerin tutumlarına, inançlarına ve programa devamlılıklarına etki etmektedir. Ayrıca uzaktan eğitim daha fazla motivasyon gerektirmektedir. Uzaktan eğitim ortamında öğrencilerin kendilerini sürekli motive olmuş bir şekilde tutmaları zor olduğu için kendilerini yalnız hissedebilmekte ve motivasyon kaybı sonucunda uzaktan eğitim programını terk etmektedirler (Akandere ve diğerleri, 2010; Azizoğlu ve Çetin, 2009; Kaya, 2013; Özan ve diğerleri, 2010; Seven ve Engin, 2008). Benzer sonuçlar çevrimiçi öğrenme hazır bulunuşluğunda da görülmektedir (Demir Kaymak ve Horzum, 2013; Polat ve İşman, 2013; Sop, 2016; Ünal ve Özdemir, 2008).

\section{Problem Durumu}

Pandemi olarak ilan edilen COVID-19 salgınının sosyal ve eğitimsel etkilerinin değerlendirilmesi sadece ülkemiz bağlamında değil Dünya bağlamında da önemli bir konu olmuştur. Çin'de ortaya çıkan COVID-19'un tüm dünyaya yayılması sonucunda Türkiye'de 2020 yılı Mart ayında yüz yüze eğitim-öğretim faaliyetlerine ara verilmiştir (YÖK, 2020). Oluşan bu ani ve olağanüstü durum tüm kademelerdeki öğrencilerin öğretimlerinin çevrimiçi ortama taşınmasını mecburi hale getirmiştir ve öğrencilerin öğretimleri halen çevrimiçi olarak yürütülmektedir. Özellikle üniversitelerde bu geçiş süreci üniversitelerin teknik altyapıları nedeniyle farklılıklar göstermiştir. Teknik alt yapının sağlanmasının yanı sıra çevrimiçi öğrenme ortamının parçası olan öğretmen ve öğrencilerin ne kadar hazır oldukları önemli bir unsurdur. Çünkü özellikle erişilebilirlik ve kapsayıcılık ilkelerini barındırması beklenen öğretim, bu süreçte teknik ve insancıl pek çok konuda problemli duruma gelmiştir. Bu aniden gelişen kriz sadece kısa vadeli bir sorun olmayıp, aynı zamanda beklenen eşitsizlikleri artıracağı için özellikle etkilenen toplumlarda kalıcı ve uzun vadeli sonuçlar doğurabilir (Nguyen ve Huynh, 2020). Pandemi sürecinde eğitimde yaşanan hızlı değişimde karşılaşılabilecek sorunlara ilişkin sınırlı sayıdaki akademik çalışma, ortaya çıkabilecek sorunları öngörmeyi zorlaştırmıştır. Bu nedenle birçok öğrenci ve öğretmenin karşılaşabileceği olası tüm zorlukları araştırmak için sınırlı bir sürede yapılan çalışmaların sonuçları, uzun vadede eğitimdeki krizin aşılmasına katkı sağlayabilir. Sosyal hayatın hızla değiştiği bu süreçte, yüz yüze öğretim yapılmayan öğrencilerin karşılaştıkları sorunların, imkânların ve hazır bulunuşluklarının incelenerek analiz edilmesi, gelecekte ortaya çıkacak pandemiler için önlemler alınması açısından çok önemlidir.

Uzaktan eğitimi etkileyen unsurlar konusunda pek çok sınıflama yer almaktadır. Bu sınıflamalar içinde "sistem kalitesi, içerik kalitesi, hizmet kalitesi, öğreticilerin tutumu, öğrencilerin bakış açısı ve destekleyici konular" gibi faktörlerele alınmaktadır (Özkan ve Köseler, 2009). Sun ve diğerlerine (2008) göre bu altı faktörün e-öğrenme süreci üzerinde olumlu etkisi vardır. Nguyen ve Huynh (2020) uzaktan eğitimi etkileyen faktörleri insan faktörleri ve teknoloji faktörleri olmak üzere 
iki kategoriye ayırmaktadır. İnsan faktörlerinin kapsamı, e-öğrenmeyi anlamak için öğrencinin psikolojik ihtiyaçlarının tanımlanması gerekliliğine dayanmaktadır. Başka bir deyişle insan faktörleri, öğrencilerin tutumları, hazır bulunuşlukları, kendi öğrenim süreçlerini düzenlemeleri ve yönetmeleri, öz üretkenlikleri (Özkan ve Köseler, 2009), kendine güvenleri (Passerini ve Granger, 2000) ile öğretmenlerin tutumları, katkıları ve motivasyon destekleri (Kim ve diğerleri, 2012) gibi unsurlar içermektedir. COVID-19 pandemi süreci öncesi yapılan uzaktan eğitime etki eden faktörlere ilişkin çalışmalardaki örneklem gruplarından farklı olarak, günümüzde çevrimiçi öğrenme sürecine katılmak zorunda kalan ve sosyal ortamından kopan öğrenciler karşımıza çıkmaktadır. Her ne kadar ülkemizde üniversiteler çevrimiçi veya çevrimdışı eğitim-öğretim sürecini çeşitli içeriklerle yürütmeye çalışsa da sadece teknik alt yapı ve içerik yeterli değildir. Çünkü çevrimiçi dersler içerik ve materyal açısından zengin, iyi tasarlanmış olsa da, öğrencilerin bakış açıları, tutumları ve motivasyonları uygun değilse, e-öğrenme başarılı olmamaktadır (Passerini ve Granger, 2000).

Pandemi sürecinde yüz yüze öğretimin alternatifi olan e-öğrenme uygulamalarının başarıya ulaşması, öğretimin sürdürülebilirliği açısından önemlidir (Nguyen ve Huynh, 2020). Bu nedenle eöğrenme başarısını doğrudan etkileyen insan faktörü unsurlarından hazır bulunuşluk ve motivasyonun pandemi sürecinde incelenmesi, sürecin uzaması veya kalıcı hale gelmesi durumunda e-öğrenmenin başarılı bir şekilde yürütülmesi için planlama yapılmasına yardımcı olabilir. Hazır bulunuşluk ve motivasyon düzeyleri arasındaki ilişkinin ortaya konulmasının uzaktan eğitim ortamında öğrenim görmekte olan öğrencilerin öğretimlerinin verimli ve başarılı olması için bu değişkenlere ilişkin düzenleme yapılmasını kolaylaştıracağı düşünülmüş ve bu çalışmanın yapılmasına karar verilmiştir. Bu bağlamda çalışmanın amacı COVID-19 pandemi sürecinde yüz yüze öğretimleri kesintiye uğrayan ve uzaktan eğitime geçen eğitim fakültesi öğrencilerinin çevrimiçi öğrenme hazır bulunuşluk ve e-öğrenme ortamlarına yönelik motivasyon düzeylerini belirlemektir. Çalışmada ayrıca, öğrencilerin çevrimiçi öğrenmeye hazır bulunuşluk ve e-öğrenme ortamlarına yönelik motivasyon düzeyleri arasındaki ilişkiyi incelemek de amaçlanmıştır. Bu amaç doğrultusunda aşağıdaki araştırma sorularına cevap aranmıştır:

1- Pandemi sürecinde öğrencilerin çevrimiçi öğrenme hazır bulunuşlukları ve e-öğrenme ortamlarına yönelik motivasyonları hangi düzeydedir?

2- Pandemi sürecinde öğrencilerin çevrimiçi öğrenme hazır bulunuşluk ve e-öğrenme ortamlarına yönelik motivasyon düzeyleri çeşitli değişkenlere göre (cinsiyet, sınıf düzeyi, bilgisayara sahip olma, internet erişimine sahip olma, bilgisayar kullanma süresi, internet kullanma süresi, çevrimiçi ve çevrimdışı derse katılma durumu, uzaktan eğitim sisteminde geçirilen süre) farklılaşmakta mıdır?

3- Pandemi sürecinde öğrencilerin çevrimiçi öğrenme hazır bulunuşluk ve e-öğrenme ortamlarına yönelik motivasyon düzeyleri arasında anlamlı bir ilişki var mıdır?

\section{Yöntem}

\section{Araştırma Modeli}

Çalışmada araştırma deseni olarak keşfedici korelasyonel araştırma modeli belirlenmiştir. Keşfedici korelasyonel araştırma modeli, değişkenler arasındaki ilişkileri çözümleyerek önemli bir olayı anlamaya çalışmak için kullanılır (Büyüköztürk ve diğerleri, 2009). Araştırmada bağımsız değişken olarak demografik değişkenler (cinsiyet, sınıf düzeyi, bilgisayara sahip olma, internet erişimine sahip olma, bilgisayar kullanma süresi, internet kullanma süresi, çevrimiçi ve çevrimdış1 derse katılma durumu, uzaktan eğitim sisteminde geçirilen süre) kullanılmıştır. Bağımlı değişkenler ise çevrimiçi öğrenme hazır bulunuşluk düzeyi ile e-öğrenme ortamlarına yönelik motivasyon düzeyidir. 


\section{Örneklem}

Çalışmanın örneklemi, 2019-2020 eğitim-öğretim yılı bahar yarıyılında (pandemi sürecinde) Türkiye'nin batısında bulunan bir eğitim fakültesinde öğrenim gören öğrencilerden uygun örnekleme yöntemiyle seçilen 221 kişiden oluşmaktadır. Seçkisiz olmayan örnekleme yöntemlerinden birisi olan uygun örnekleme yönteminde zaman, para ve işgücündeki sınırlılıklar açısından örneklemin kolay ulaşılabilir ve uygulama yapılabilir olması amaçlanır (Büyüköztürk ve diğerleri, 2009). Çalışmaya ilgili eğitim fakültesinde yer alan Ortaöğretim Matematik Eğitimi, Bilgisayar ve Öğretim Teknolojileri Eğitimi, Sınıf Eğitimi, Okul Öncesi Eğitimi, İlköğretim Matematik Eğitimi, Fen Bilgisi Eğitimi, Sosyal Bilgiler Eğitimi bölümlerinden öğrenciler katılmıştır. Her bir bölüm için bölümü temsil edecek yeterli öğrenciye ulaşılamadığ için öğrenim görülen bölüm değişkeni çalışmaya dahil edilmemiştir. Örneklemde bulunan öğrencilerin demografik özelliklerine göre dağglımları Tablo 1 'de verilmiştir.

Tablo 1: Örneklemde Bulunan Öğrencilerin Demografik Özellikleri

\begin{tabular}{llcccc}
\hline & & \multicolumn{2}{c}{ Cinsiyet } & & \\
& & Kadın & Erkek & \multicolumn{2}{c}{ Toplam } \\
\hline Sınıf düzeyi & 1 & $\mathrm{f}$ & $\mathrm{f}$ & $\mathrm{f}$ & $\%$ \\
& 2 & 26 & 6 & 32 & 14.48 \\
& 3 & 52 & 18 & 70 & 31.68 \\
& 4 ve yukarı & 40 & 14 & 54 & 24.43 \\
& Evet & 116 & 23 & 65 & 29.41 \\
\hline Bilgisayara sahip olma durumu & Hayır & 44 & 13 & 164 & 74.21 \\
& Evet & 130 & 52 & 182 & 83.79 \\
\hline Internete erişimine sahip olma durumu & Hayır & 30 & 9 & 39 & 17.65 \\
\hline Bilgisayar kullanım süresi & 1 yıldan aşağı & 11 & 3 & 14 & 6.34 \\
& $1-3$ yıl & 10 & 3 & 13 & 5.88 \\
& $4-6$ yıl & 23 & 6 & 29 & 13.12 \\
& $7-9$ yıl & 40 & 10 & 50 & 22.62 \\
& 10 yıldan yukarı & 76 & 39 & 115 & 52.04 \\
\hline Günlük internet kullanım süresi & 2 saat ve aşağısı & 37 & 10 & 47 & 21.27 \\
& 3-4 saat & 60 & 24 & 84 & 38.01 \\
& 5 saat ve yukarısı & 63 & 27 & 90 & 40.72 \\
\hline Çevrimiçi derse katılma durumu & Evet & 49 & 25 & 74 & 33.48 \\
& Hayır & 111 & 36 & 147 & 66.52 \\
\hline Çevrimdışı derse katılma durumu & Evet & 76 & 33 & 109 & 49.32 \\
& Hayır & 84 & 28 & 112 & 50.68 \\
\hline Uzaktan eğitim sisteminde geçirilen süre & 1 saatten aşağı & 75 & 32 & 107 & 48.42 \\
& $1-3$ saat & 56 & 17 & 73 & 33.03 \\
& 4-6 saat & 16 & 9 & 25 & 11.31 \\
& 7 saatten yukarı & 13 & 3 & 16 & 7.24 \\
\hline Toplam & & 160 & 61 & 221 & 100 \\
\hline Not. N=221 & & & & & \\
& & & & &
\end{tabular}

Tablo 1 incelendiğinde çalışmaya katılan eğitim fakültesi öğrencilerinin 160'nın (\%72.40) kadın, 61'inin (\%27.60) erkek; 32'sinin (\%14.48) birinci sınıf, 70'inin (\%31.68) ikinci sınıf, 54'ünün (\%24.43) üçüncü sınıf, 65'inin (\%29.41) dördüncü sınıf ve yukarısı olduğu görülebilir. Elde edilen bulgulara göre öğrencilerin \%74.21'inin bilgisayara sahip olduğu, \%83.35'inin internet erişimine sahip olduğu, \%52.04'ünün 10 yıldan fazla süredir bilgisayar kullandı ğı, \% 40.72'sinin günlük 5 saat ve yukarısı süreyle internet kullandığı, \%33.48'inin çevrimiçi derse katıldığı, \%49.32'sinin çevrimdışı derse katıldığ $1, \% 48.42$ 'sinin bir saatten aşağı süreyi uzaktan eğitim sisteminde geçirdiği belirlenmiştir. 


\section{Veri Toplama Araçları}

Çalışmanın verilerinin toplanmasında üç bölümden oluşan anket kullanılmıştır. Birinci bölümde eğitim fakültesi öğrencilerinin demografik bilgilerine (cinsiyet, sınıf düzeyi, bilgisayara sahip olma durumu, internet erişimine sahip olma durumu, bilgisayar kullanma süresi, internet kullanma süresi, çevrimiçi ve çevrimdışı derse katılma durumu, uzaktan eğitim sisteminde geçirilen süre) ulaşmak için araştırmacılar tarafından oluşturulan bilgi formu yer almaktadır. İkinci bölümde katılımcıların çevrimiçi öğrenme hazır bulunuşluklarını ölçmek için Yurdugül ve Alsancak Sırakaya (2013) tarafından Türkçeye uyarlanan Çevrimiçi Öğrenme Hazır Bulunuşluluk Ölçeği [ÇÖHBÖ] kullanılmıştır. Üçüncü bölümde ise katılımcıların e-öğrenme ortamlarına yönelik motivasyon düzeylerini belirlemek için Yıldırım (2012) tarafından Türkçeye uyarlanan E-Öğrenme Ortamlarına Yönelik Motivasyon Anketi [EÖYMA] kullanılmıştır. Çalışma esnasında etik kurul onayı için Balıkesir Üniversitesi'ne başvurulmuş ve araştırma etiğine aykırı bir durum olmadığı 24.12.2020 tarih ve E-19928322-302.08.01-1681 sayılı etik kurul izin belgesi ile onaylanmıştır.

ÇÖHBÖ, Hung ve diğerleri (2010) tarafından geliştirilmiştir, Yurdugül ve Alsancak Sırakaya (2013) tarafindan Türkçeye uyarlaması yapılmıştır. Toplam 18 maddeden oluşan beşli likert tipinde bir ölçektir. Ölçekte, hiç katılmıyorum (1), katılmıyorum (2), kararsızım (3), katılıyorum (4), tamamen katılıyorum (5) şeklinde beş seçenek yer almaktadır. Katılımcıların ölçek sorularına verdikleri yanıtların toplamının anketteki soru sayısına bölünmesi ile bulunan ÇÖHBÖ puanlarının değerlendirilmesinde 1.00-1.80: hiç katılmıyorum, 1.81-2.60: katılmıyorum, 2.61-3.40: kararsızım, 3.41-4.20: katılıyorum, 4.21-5.00 tamamen katılıyorum ölçeklemesi kullanılmıştır. Ölçek puanları 1.00 ile 5.00 arasında olduğu için puanlar 5.00'e yaklaştıkça öğrencilerin ölçek maddelerine katılım düzeylerinin yüksek, 1.00'e yaklaştıkça düşük olduğu kabul edilmiştir. Ölçekte olumsuz madde yer almamaktadır ve ÇÖHBÖ'nin güvenilirlik katsayısı Yurdugül ve Alsancak Sırakaya (2013) tarafından 0.87 olarak bulunmuştur. Bu çalışmada elde edilen verilerle ÇÖHBÖ'nin Cronbach'ın alfa güvenirlik katsayısı 0.864 olarak hesaplanmıştır.

EÖYMA, Kim (2005) tarafından geliştirilmiştir, Yıldırım (2012) tarafından Türkçeye uyarlanmıştır. Toplam 33 maddeden oluşan beşli likert tipinde bir ölçektir. Ölçekte, hiç katılmıyorum (1), katılmıyorum (2), kararsızım (3), katılıyorum (4), tamamen katılıyorum (5) şeklinde beş seçenek yer almaktadır. Katılımcıların anket sorularına verdikleri yanıtların toplamının anketteki soru sayısına bölünmesi ile bulunan EÖYMA puanlarının değerlendirilmesinde 1.00-1.80: hiç katılmiyorum, 1.81-2.60: katılmiyorum, 2.61-3.40: kararsızım, 3.41-4.20: kat1lyorum, 4.21-5.00 tamamen katılıyorum ölçeklemesi kullanılmıştır. Puanlar 1.00 ile 5.00 arasında olduğundan puanlar 5.00'e yaklaştıkça öğrencilerin ankete katılım düzeylerinin yüksek, 1.00 'e yaklaştıkça düşük olduğu kabul edilmiştir. Ankette yer alan olumsuz maddelerin ölçeklendirilmesi puanlama aşamasında ters çevrilmiştir. EÖYMA'nın güvenirlik katsayısı Yıldırım (2012) tarafından 0.70 olarak bulunmuştur. Bu çalışmada elde edilen verilerle EÖYMA'nın Cronbach'ın alfa güvenirlik katsayısı 0.806 olarak hesaplanmıştır. Bulunan güvenirlik katsayısı değerlerinin 0.70'ten yüksek çıkması, kullanılan veri toplama araçlarının güvenilir olduğu şeklinde ifade edilebilir (Büyüköztürk, 2020).

\section{Verilerin Analizi}

Çalışmada toplanan verilerin çözümlenmesinde istatistiksel analiz paket programı (IBM SPSS Statistics 24) kullanılmıştır. ÇÖHBÖ ve EÖYMA puanlarının dağılımlarını belirlemek amacıyla betimsel istatistiklerden yararlanılmıştır. Verilerin analizinde parametrik veya parametrik olmayan testlerden hangisinin kullanılacağını belirlemek için katılımcıların ölçeklerden almış oldukları puanlar hesaplanmış ve puanların bağımsız değişkenlere göre normal dağılım gösterip göstermediğine karar vermek için basıklık ve çarpıklık değerleri incelenmiştir (Büyüköztürk, 2020). Öğrencilerin ÇÖHBÖ ve EÖYMA puanlarının çarpıklık ve basıklık değerleri ile puanların cinsiyet, sınıf düzeyi, bilgisayara sahip olma, internet erişimine sahip olma, bilgisayar kullanma süresi, internet kullanma süresi, çevrimiçi ve çevrimdışı derse katılma durumu, uzaktan eğitim sisteminde geçirilen süre değişkenlerine göre çarpıklık ve basıklık değerleri Tablo 2'de gösterilmiştir. 
Tablo 2: ÇÖHBÖ ve EÖYMA Puanlarının Çarpıklık ve Basıklık Değerleri

\begin{tabular}{|c|c|c|c|c|}
\hline Ölçekler & Değişkenler & & Çarpıklık & Basıklık \\
\hline \multirow[t]{27}{*}{ ÇÖHBÖ } & - & - & -.283 & .347 \\
\hline & \multirow{2}{*}{ Cinsiyet } & Kadın & -.332 & .561 \\
\hline & & Erkek & -.251 & -.057 \\
\hline & \multirow{4}{*}{ Sınıf düzeyi } & 1 & -.040 & .784 \\
\hline & & 2 & -.572 & 606 \\
\hline & & 3 & -.098 & .255 \\
\hline & & 4 ve yukarıs1 & -.170 & -.023 \\
\hline & \multirow[t]{2}{*}{ Bilgisayara sahip olma durumu } & Evet & -.080 & .220 \\
\hline & & Hayır & -.305 & -.118 \\
\hline & \multirow{2}{*}{ İnternete erişimine sahip olma durumu } & Evet & -.303 & .346 \\
\hline & & Hayır & -.020 & -.016 \\
\hline & \multirow[t]{5}{*}{ Bilgisayar kullanma süresi } & 1 yldan az & -.296 & -1.136 \\
\hline & & $1-3$ yll & -.439 & .203 \\
\hline & & $4-6$ y1l & .046 & .373 \\
\hline & & $7-9$ y1l & -.493 & 1.007 \\
\hline & & 10 yildan fazla & -.362 & .785 \\
\hline & \multirow[t]{3}{*}{ İnternet kullanma süresi } & 2 saat ve aşağısı & -.236 & -.249 \\
\hline & & 3-4 saat & .047 & .576 \\
\hline & & 5 saat ve yukarıs1 & -.554 & 605 \\
\hline & \multirow{2}{*}{ Çevrimiçi derse katılma durumu } & Evet & -.064 & -.025 \\
\hline & & Hayır & -.381 & .458 \\
\hline & \multirow[t]{2}{*}{ Çevrimdışı derse katılma durumu } & Evet & -.567 & 1.123 \\
\hline & & Hayır & -.046 & -.034 \\
\hline & \multirow[t]{4}{*}{ Uzaktan eğitim sisteminde geçirilen süre } & 1 saatten az & -.221 & -.116 \\
\hline & & $1-3$ saat & -.016 & -.151 \\
\hline & & 4-6 saat & -.042 & -.586 \\
\hline & & 7 saatten fazla & .944 & .398 \\
\hline \multirow{27}{*}{ EÖYMA } & - & - & -.161 & -.254 \\
\hline & \multirow{2}{*}{ Cinsiyet } & Kadın & -.160 & -.097 \\
\hline & & Erkek & -.166 & -.630 \\
\hline & \multirow[t]{4}{*}{ Sinıf düzeyi } & 1 & .096 & -.613 \\
\hline & & 2 & -.084 & -.021 \\
\hline & & 3 & -.238 & -.620 \\
\hline & & 4 ve yukarıs1 & .089 & -.566 \\
\hline & \multirow[t]{2}{*}{ Bilgisayara sahip olma durumu } & Evet & -.120 & -.125 \\
\hline & & Hayır & -.118 & -.635 \\
\hline & \multirow[t]{2}{*}{ İnternete erişimine sahip olma durumu } & Evet & -.264 & -.180 \\
\hline & & Hayır & .304 & .264 \\
\hline & \multirow[t]{5}{*}{ Bilgisayar kullanma süresi } & 1 yldan az & .472 & -.783 \\
\hline & & $1-3$ yll & .324 & -.036 \\
\hline & & $4-6$ y1l & -.438 & -.885 \\
\hline & & $7-9$ y1l & -.037 & .339 \\
\hline & & 10 yildan fazla & -.259 & .001 \\
\hline & \multirow[t]{3}{*}{ İnternet kullanma süresi } & 2 saat ve aşağıs1 & -.106 & -.814 \\
\hline & & 3-4 saat & -.046 & .138 \\
\hline & & 5 saat ve yukarıs1 & -.291 & -.239 \\
\hline & \multirow[t]{2}{*}{ Çevrimiçi derse katılma durumu } & Evet & -.322 & -.604 \\
\hline & & Hayır & -.073 & -.005 \\
\hline & \multirow[t]{2}{*}{ Çevrimdışı derse katılma durumu } & Evet & -.182 & -.213 \\
\hline & & Hayır & -.079 & -.522 \\
\hline & Uzaktan eğitim sisteminde geçirilen süre & 1 saatten az & -.193 & $\begin{array}{l}-138 \\
\end{array}$ \\
\hline & & $1-3$ saat & -.509 & -.373 \\
\hline & & 4-6 saat & -.403 & -.690 \\
\hline & & 7 saatten fazla & .869 & .177 \\
\hline
\end{tabular}


Büyüköztürk (2020)'e göre basıklık ve çarpıklık değerleri -1.0 ve +1.0 aralığında, Tabachnick ve Fidell (2013)'e göre ise -1.5 ve +1.5 aralığında bulunuyorsa verilerin normal dağılım koşulunu yerine getirdiği varsayılmaktadır. Buna göre Tablo 2'deki değerler incelenmiş ve verilerin normal dağılımdan önemli ölçüde sapma göstermediği sonucuna ulaşılmıştır. Veriler normal dağılım gösterdiği için öğrencilerin çevrimiçi öğrenme hazır bulunuşluk ve e-öğrenme ortamlarına yönelik motivasyon puanlarının, cinsiyet, bilgisayara sahip olma durumu, internet erişimine sahip olma durumu, çevrimiçi ve çevrimdışı derse katılma durumu değişkenlerine göre farklılaşıp farklılaşmadığını belirlemek için ilişkisiz örneklemler için t-testi; sınıf düzeyi, bilgisayar kullanma süresi, internet kullanma süresi ve uzaktan eğitim sisteminde geçirilen süre değişkenlerine göre farklılaşıp farklılaşmadığını belirlemek için ilişkisiz örneklemler için tek yönlü varyans analizi [ANOVA] yapılmıştır. Yapılan analizler sonucunda post hoc test olarak varyansların eşitliği durumunda Scheffe, eşit olmaması durumunda ise Dunnett's C testi kullanılmıştır (Büyüköztürk, 2020). İlişkisiz örneklemler için t-testi, ilişkisiz iki gruba ait puanların ortalamaları arasındaki farkın anlamlı olup olmadığını test etmek amacıyla kullanılırken, ANOVA ise birbirleri arasında ilişki olmayan ikiden fazla gruba ait puan ortalamaları arasındaki farkın anlamlı olup olmadığını test etmek amacıyla kullanılır. Her iki testte de bağımlı değişkene ilişkin ölçümlerin normal dağılım göstermesi gerekmektedir (Büyüköztürk, 2020).

ÇÖHBÖ ve EÖYMA puanlarının arasındaki ilişki Pearson korelasyon katsayısı hesaplanarak incelenmiştir. Korelasyon katsayısı, iki değişkenin arasındaki ilişkinin derecesini ölçmek amaciyla kullanılır. Pearson korelasyon katsayısı, iki değişkenin de sürekli olmasını ve değişkenlerin birlikte normal dağılım göstermesini gerekmektedir (Büyüköztürk, 2020). İzleyen bölümde, araştırma problemlerine yönelik elde edilen bulgular ve yorumlara yer verilmiştir.

\section{Bulgular}

Araştırmanın ilk alt problemi olan "Pandemi sürecinde öğrencilerin çevrimiçi öğrenme hazır bulunuşlukları ve e-öğrenme ortamlarına yönelik motivasyonları hangi düzeydedir?" sorusunun yanıtı için öğrencilerin ÇÖHBÖ ve EÖYMA puanlarına ait betimsel istatistikler hesaplanmıştır. Betimsel istatistikler Tablo 3'te verilmiştir.

Tablo 3: ÇÖHBÖ ve EÖYMA Puanlarına ait Betimsel İstatistikleri

\begin{tabular}{cccccc}
\hline Ölçekler & $\mathrm{f}$ & Minimum & Maksimum & $\bar{X}$ & $\mathrm{~S}$ \\
\hline ÇÖHBÖ & 221 & 2.22 & 4.88 & 3.67 & .467 \\
EÖYMA & 221 & 2.21 & 4.09 & 3.12 & .364 \\
\hline
\end{tabular}

Not. f: frekans, $\bar{X}$ : ortalama, S: Standart sapma

Tablo 3 incelendiğinde, ÇÖHBÖ puanlarının ortalamasının $\bar{X}=3.67$ olduğu görülebilir. Bu puanın verilerin analizi bölümünde belirtilen ölçeklemeye göre "katılıyorum" seçeneğine denk geldiği, dolayısı ile örneklemdeki eğitim fakültesi öğrencilerinin çevrimiçi öğrenme hazır bulunuşluklarının yüksek düzeyde olduğu yorumu yapılabilir. Aynı şekilde Tablo 3 incelendiğinde EÖYMA puanlarının ortalamasının $\bar{X}=3.12$ olduğu görülmektedir. Bu puan ölçeklemeye göre "kararsızım" düzeyine denk geldiği, dolayısı ile örneklemdeki eğitim fakültesi öğrencilerinin eöğrenme ortamlarına yönelik motivasyonlarının çok fazla düşük düzeyde olmadığı şeklinde yorumlanabilir.

ÇÖHBÖ’ye öğrencilerin verdikleri yanıtlar madde madde incelendiğinde "Yazılı iletişimde kendimi ifade etmede (duygular ve espri) kendime güvenirim." maddesini en çok sayıda kişinin "tamamen katılıyorum" (\% 24.89) ve "katılıyorum" (\%56.10) olarak işaretlediği görülmüştür. Buna göre örneklemdeki eğitim fakültesi öğrencilerinin çoğunun yazılı iletişimde kendilerini ifade etmeye yönelik hazır bulunuşluklarının yüksek olduğu yorumu yapılabilir. ÇÖHBÖ'deki "Çevrimiçi öğrenirken diğer çevrimiçi faaliyetlerden (anlık mesajlaşma, internette dolaşma) dolayı dikkatim dağılmaz." maddesini 32 kişi (\%14.48) "hiç katılmıyorum", 70 kişi (\%31.67) "katılmıyorum" olarak işaretlemiştir. En çok sayıda kişi tarafından "hiç katılmıyorum" ve "katılmıyorum" olarak işaretlenen 
bu maddeye bakılarak öğrencilerin çevrimiçi ortamda öğrenmelerini kontrol etmede zorlandıkları ve dolayısıyla bu konuda çevrimiçi öğrenme hazır bulunuşluklarının yüksek olmadığı yorumu yapilabilir.

EÖYMA'ya öğrencilerin verdikleri yanıtlar madde madde incelendiğinde "Bu derste yüz yüze konuşabileceğim bir öğretmenin olması öğrenmeme olumlu yönde yansiyabilirdi." maddesini en çok sayıda kişinin "tamamen katılıyorum" (\%37.10) ve "katılıyorum" (\%38.46) olarak işaretlediği görülmüştür. Buna göre örneklemdeki öğrencilerin çoğunun uzaktan eğitim sistemindeki dersler için yüz yüze iletişim kuracağı bir öğretmenin varlığının e-öğrenme ortamlarına yönelik motivasyonlarını yükselttiği yorumu yapılabilir. EÖYMA'daki "Süreçleri yönetebildiğim bir uzaktan ders almak benim için değerliydi." maddesini 23 kişi (\%10.40) "hiç katılmıyorum", 33 kişi (\%14.93) "katılmıyorum" olarak işaretlemiştir. En çok sayıda kişi tarafindan "hiç katılmıyorum" ve "katılmıyorum" olarak işaretlenen bu maddeye bakılarak öğrencilerin uzaktan eğitim sürecinde öz denetimlerini sağlamada zorlandıklarını ve bu konuda e-öğrenme ortamlarına yönelik motivasyonlarının yüksek olmadığı yorumu yapılabilir.

Araştırmanın ikinci alt problemi olan "Pandemi sürecinde öğrencilerini çevrimiçi öğrenme hazır bulunuşluk ve e-öğrenme ortamlarına yönelik motivasyon düzeyleri çeşitli değişkenlere göre (cinsiyet, sınıf düzeyi, bilgisayara sahip olma, internet erişimine sahip olma, bilgisayar kullanma süresi, internet kullanma süresi, çevrimiçi ve çevrimdışı derse katılma durumu, uzaktan eğitim sisteminde geçirilen süre) farklılaşmakta mıdır?" sorusunun yanıtı için bağımsız değişkenlere göre ÇÖHBÖ ve EÖYMA puanları incelenmiştir. Veriler normal dağılım gösterdiği için cinsiyet, bilgisayara sahip olma, internet erişimine sahip olma, çevrimiçi ve çevrimdışı derse katılma durumu değişkenlerine göre farklılaşıp farklılaşmadığını belirlemek için ilişkisiz örneklemler için t-testi yapılmıştır. Yapılan ilişkisiz örneklemler için t-testi sonuçları Tablo 4 'te yer verilmiştir.

Tablo 4: ÇÖHBÖ ve EÖYMA Puanlarının Çeşitli Değişkenlere göre t-Testi Sonuçları

\begin{tabular}{|c|c|c|c|c|c|c|c|c|}
\hline \multirow{11}{*}{$\frac{\text { Ölçekler }}{\text { ÇÖHBÖ }}$} & Değişkenler & & $\mathrm{N}$ & $\bar{X}$ & $\mathrm{~S}$ & $\mathrm{sd}$ & $\mathrm{t}$ & $\mathrm{p}$ \\
\hline & \multirow{2}{*}{ Cinsiyet } & Kadın & 160 & 3.66 & .440 & 219 & .486 & .627 \\
\hline & & Erkek & 61 & 3.69 & .532 & & & \\
\hline & \multirow{2}{*}{ Bilgisayara sahip olma durumu } & Evet & 164 & 3.70 & .426 & 219 & 1.804 & .075 \\
\hline & & Hayır & 57 & 3.56 & .558 & & & \\
\hline & \multirow[t]{2}{*}{ İnternet erişimine sahip olma durumu } & Evet & 182 & 3.69 & .436 & 219 & 1.143 & .259 \\
\hline & & Hayır & 39 & 3.57 & .586 & & & \\
\hline & \multirow[t]{2}{*}{ Çevrimiçi derse katılma durumu } & Evet & 74 & 3.75 & .456 & 219 & 1.806 & .072 \\
\hline & & Hayır & 147 & 3.63 & .468 & & & \\
\hline & \multirow[t]{2}{*}{ Çevrimdışı derse katılma durumu } & Evet & 109 & 3.70 & .440 & 219 & 1.131 & .359 \\
\hline & & Hayır & 112 & 3.64 & .490 & & & \\
\hline \multirow[t]{10}{*}{ EÖYMA } & \multirow[t]{2}{*}{ Cinsiyet } & Kadın & 160 & 3.10 & .365 & 219 & .786 & .433 \\
\hline & & Erkek & 61 & 3.15 & .363 & & & \\
\hline & \multirow{2}{*}{ Bilgisayara sahip olma durumu } & Evet & 164 & 3.15 & .350 & 219 & 2.444 & .015 \\
\hline & & Hayır & 57 & 3.01 & .388 & & & \\
\hline & \multirow[t]{2}{*}{ İnternet erişimine sahip olma durumu } & Evet & 182 & 3.14 & .363 & 219 & 2.200 & .029 \\
\hline & & Hayır & 39 & 3.00 & .351 & & & \\
\hline & \multirow[t]{2}{*}{ Çevrimiçi derse katılma durumu } & Evet & 74 & 3.21 & .347 & 219 & 2.818 & .005 \\
\hline & & Hayır & 147 & 3.07 & .364 & & & \\
\hline & \multirow[t]{2}{*}{ Çevrimdışı derse katılma durumu } & Evet & 109 & 3.10 & .394 & 219 & .542 & .589 \\
\hline & & Hayır & 112 & 3.13 & .334 & & & \\
\hline
\end{tabular}

Not. N: kişi sayısı, $\bar{X}$ : ortalama, S: Standart sapma, sd: serbestlik derecesi

Tablo 4 incelendiğinde, erkek katılımcıların ÇÖHBÖ ve EÖYMA puanlarının ortalamasının, kadın katılımcıların puanlarının ortalamasından daha yüksek olduğu söylenebilir. Gözlenen bu farkın anlamlılığını belirlemek için yapılan ilişkisiz örneklemler için t-testi sonuçları incelendiğinde kadın 
ve erkek katılımcıların ÇÖHBÖ puanlarının ortalamalarının [t(219)=.486, $\mathrm{p}>.05]$ ve EÖYMA puanlarının ortalamalarının [t(219)=.786, $\mathrm{p}>.05]$ anlamlı bir şekilde farklılaşmadığı görülebilir. $\mathrm{Bu}$ bulgu, cinsiyet ile ÇÖHVÖ ve EÖYMA puanları arasında istatistiksel olarak anlamlı bir ilişkinin olmadığ 1 şeklinde yorumlanabilir (Büyüköztürk, 2020). Bilgisayara sahip olan katılımcıların ÇÖHBÖ ve EÖYMA puanlarının ortalamasının, bilgisayara sahip olmayan katılımcıların puanlarının ortalamasından daha yüksek olduğu söylenebilir. T-testi sonuçları incelendiğinde bilgisayara sahip olan ve olmayan katılımcıların ÇÖHBÖ puanlarının ortalamalarının anlamlı bir şekilde farklılaşmadığı $[\mathrm{t}(219)=1.804, \mathrm{p}>.05]$ görülürken, katılımcıların EÖYMA puanlarının ortalamalarının anlamlı bir şekilde farklılaştı̆g $1 \mathrm{t}(219)=2.444, \mathrm{p}<.05]$ görülmektedir. Bu bulgular bilgisayara sahip olma durumu ile ÇÖHBÖ puanları arasında anlamlı bir ilişkinin olmadığı şeklinde yorumlanabilirken, bilgisayara sahip olma durumu ile EÖYMA puanları arasında anlamlı bir ilişkinin olduğu şeklinde yorumlanabilir (Büyüköztürk, 2020). İnternet erişimine sahip olan katılımcıların ÇÖHBÖ ve EÖYMA puanlarının ortalamasının, internet erişimine sahip olmayan katılımcıların puanlarının ortalamasından daha yüksek olduğu söylenebilir. Gözlenen bu farkın anlamlılığını belirlemek için yapılan t-testi sonuçları incelendiğinde internet erişimine sahip olan ve internet erişimine sahip olmayan katılımcıların ÇÖHBÖ puanlarının ortalamalarının anlamlı bir şekilde farklılaşmadığ 1 görülmektedir, $\mathrm{t}(219)=1.143$, $\mathrm{p}>.05$. İnternet erişimine sahip olma durumuna göre katılımcıların EÖYMA puanlarının ortalamalarının anlamlı bir şekilde farklılaştığı ifade edilebilir, $\mathrm{t}(219)=2.200, \mathrm{p}<.05$. Bu bulgular, internet erişimine sahip olma durumu ile ÇÖHBÖ puanları arasında anlamlı bir ilişki yoktur şeklinde yorumlanabilirken, internet erişimine sahip olma durumu ile EÖYMA puanları arasında anlamlı bir ilişki vardır şeklinde yorumlanabilir (Büyüköztürk, 2020).

Tablo 4 incelendiğinde, çevrimiçi derse katılan öğrencilerin ÇÖHBÖ ve EÖYMA puanlarının ortalamasının, çevrimiçi derse katılmayan öğrencilerin ÇÖHBÖ ve EÖYMA puanlarının ortalamasından daha yüksek olduğu görülmektedir. T-testi sonuçları incelendiğinde çevrimiçi derse katılan ve katılmayan öğrencilerin ÇÖHBÖ puanlarının ortalamalarının anlamlı bir şekilde farklılaşmadığı görülebilir, $\mathrm{t}(219)=1.806, \mathrm{p}>.05$. Çevrimiçi derse katılma durumuna göre öğrencilerin EÖYMA puanlarının ortalamalarının anlamlı bir şekilde farklılaştığı ifade edilebilir, $\mathrm{t}(219)=2.818, \mathrm{p}<.05$. Bu bulgular, çevrimiçi derse katılma durumu ile ÇÖHBÖ puanları arasında anlamlı bir ilişki yoktur, çevrimiçi derse katılma durumu ile EÖYMA puanları arasında anlamlı bir ilişki vardır şeklinde yorumlanabilir (Büyüköztürk, 2020). Çevrimdışı derse katılan öğrencilerin ÇÖHBÖ puanlarının ortalamasının, çevrimdışı derse katılmayan öğrencilerin ÇÖHBÖ puanlarının ortalamasından daha yüksek olduğu görülürken, çevrimdışı derse katılmayan öğrencilerin EÖYMA puanlarının ortalamasının, çevrimdışı derse katılan öğrencilerin EÖYMA puanlarının ortalamasından daha yüksek olduğu görülebilir. Gözlenen bu farkın anlamlılığını belirlemek için yapılan t-testi sonuçları incelendiğinde çevrimdışı derse katılan ve katılmayan öğrencilerin ÇÖHBÖ puanlarının ortalamalarının anlamlı bir şekilde farklılaşmadığı görülebilir, $t(219)=1.131, \mathrm{p}>.05$. Aynı şekilde EÖYMA puanlarının ortalamalarının da çevrimdışı derse katılma durumuna göre istatistiksel olarak anlamlı bir şekilde farklılaşmadığı söylenebilir, $\mathrm{t}(219)=.542, \mathrm{p}>.05$. Bu bulgular çevrimdışı derse katılma durumu ile ÇÖHBÖ puanları arasında ve çevrimdışı derse katılma durumu ile EÖYMA puanları arasında anlamlı bir ilişki olmadığı şeklinde yorumlanabilir (Büyüköztürk, 2020).

Araştırmanın ikinci alt problemine yanıt aramak için, ayrıca sınıf düzeyi, bilgisayar kullanma süresi, internet kullanma süresi ve uzaktan eğitim sisteminde geçirilen süre değişkenlerine göre öğrencilerin ÇÖHBÖ ve EÖYMA puanları incelenmiştir. Bu değişkenlere göre öğrencilerin ÇÖHBÖ ve EÖYMA puanlarının dağılımları Tablo 5'te verilmiştir. 
Tablo 5: ÇÖHBÖ ve EÖYMA Puanlarının Çeşitli Değişkenlere göre Dağılımları

\begin{tabular}{|c|c|c|c|c|c|}
\hline Ölçekler & Değişkenler & & $\mathrm{N}$ & $\bar{X}$ & $\mathrm{~S}$ \\
\hline \multirow[t]{16}{*}{ ÇÖHBÖ } & \multirow[t]{4}{*}{ Sınıf Düzeyi } & 1 & 32 & 3.55 & .421 \\
\hline & & 2 & 70 & 3.62 & .496 \\
\hline & & 3 & 54 & 3.71 & .447 \\
\hline & & 4 ve yukarısı & 65 & 3.74 & .463 \\
\hline & \multirow[t]{5}{*}{ Bilgisayar Kullanma Süresi } & 1 y1ldan az & 14 & 3.28 & .437 \\
\hline & & $1-3$ y1l & 13 & 3.40 & .393 \\
\hline & & 4-6 y1l & 29 & 3.54 & .436 \\
\hline & & $7-9$ yil & 50 & 3.70 & .463 \\
\hline & & 10 yıldan fazla & 115 & 3.76 & .450 \\
\hline & \multirow[t]{3}{*}{ İnternet Kullanma Süresi } & 2 saat ve aşağ 1 s1 & 47 & 3.62 & .558 \\
\hline & & $3-4$ saat & 84 & 3.68 & .444 \\
\hline & & 5 saat ve yukarısı & 90 & 3.68 & .439 \\
\hline & \multirow[t]{4}{*}{ Uzaktan Eğitim Sisteminde Geçirilen Süre } & 1 saatten az & 107 & 3.53 & .506 \\
\hline & & $1-3$ saat & 73 & 3.73 & .370 \\
\hline & & 4-6 saat & 25 & 3.91 & .345 \\
\hline & & 7 saatten fazla & 16 & 3.89 & .473 \\
\hline \multirow[t]{16}{*}{$\overline{\text { EÖYMA }}$} & \multirow[t]{4}{*}{ Sinıf Düzeyi } & 1 & 32 & 3.05 & .456 \\
\hline & & 2 & 70 & 3.06 & .369 \\
\hline & & 3 & 54 & 3.10 & .356 \\
\hline & & 4 ve yukarısı & 65 & 3.22 & .296 \\
\hline & \multirow[t]{5}{*}{ Bilgisayar Kullanma Süresi } & 1 yildan az & 14 & 2.90 & .386 \\
\hline & & $1-3$ y1l & 13 & 2.96 & .296 \\
\hline & & 4-6 yil & 29 & 3.04 & .372 \\
\hline & & $7-9$ yil & 50 & 3.12 & .371 \\
\hline & & 10 y1ldan fazla & 115 & 3.18 & .350 \\
\hline & \multirow[t]{3}{*}{ İnternet Kullanma Süresi } & 2 saat ve aşağısı & 47 & 3.08 & .411 \\
\hline & & $3-4$ saat & 84 & 3.14 & .365 \\
\hline & & 5saat ve yukarısı & 90 & 3.12 & .339 \\
\hline & \multirow[t]{4}{*}{ Uzaktan Eğitim Sisteminde Geçirilen Süre } & 1 saatten az & 107 & 3.01 & .344 \\
\hline & & 1-3 saat & 73 & 3.22 & .365 \\
\hline & & 4-6 saat & 25 & 3.17 & .316 \\
\hline & & 7 saatten fazla & 16 & 3.24 & .398 \\
\hline
\end{tabular}

Not. N: kişi sayıs1, $\bar{X}$ : ortalama, S: Standart sapma

Tablo 5 incelendiğinde, katılımcıların sınıf düzeyi, bilgisayar kullanma süresi, internet kullanma süresi ve uzaktan eğitim sisteminde geçirilen süre değişkenlerine göre ÇÖHBÖ ve EÖYMA puanlarının farklı olduğu görülebilir. Katılımcıların ÇÖHBÖ ve EÖYMA puanlarında görülen farklıların istatistiksel olarak anlamlılığını test etmek için ANOVA testi yapılmıştır. Yapılan ANOVA testi sonucunda ulaşılan bulgular Tablo 6' da verilmiştir.

Tablo 6: ÇÖHBÖ ve EÖYMA Puanlarının Sınıf Düzeyine göre ANOVA Sonuçları

\begin{tabular}{llccccc}
\hline Ölçekler & & Kareler Toplamı & sd & Kareler Ortalamas1 & F & $p$ \\
\hline ÇÖHBÖ & Gruplar aras1 & 1.105 & 3 & .368 & 1.705 & .167 \\
& Gruplar içi & 46.880 & 217 & .216 & & \\
& Toplam & 47.985 & 220 & & & \\
\hline \multirow{2}{*}{ EÖYMA } & Gruplar aras1 & 1.004 & 3 & .335 & 2.568 & .055 \\
& Gruplar içi & 28.270 & 217 & .130 & & \\
\cline { 2 - 7 } & Toplam & 29.273 & 220 & & \\
\hline
\end{tabular}

Tablo 6 incelendiğinde, katılımcıların ÇÖHBÖ $[F(3,217)=1.705, p>.05]$ ve EÖYMA $[F(3,217)=2,568, p>, 05]$ puan ortalamalarında sınıf düzeyine göre istatistiksel olarak anlamlı bir farklılık olmadığı görülmektedir. 
Öğrencilerin bilgisayar kullanma sürelerine göre ÇÖHBÖ ve EÖYMA puanlarında gözlenen farklılığın istatistiksel olarak anlamlı olup olmadığını belirlemek için yapılan ANOVA sonucunda ulaşılan bulgular Tablo 7'de verilmiştir.

Tablo 7: ÇÖHBÖ ve EÖYMA Puanlarının Bilgisayar Kullanma Süresine göre ANOVA Sonuçları

\begin{tabular}{llcccccc}
\hline Ölçekler & & Kareler Toplamı & sd & Kareler Ortalaması & F & p & Anlamlı fark \\
\hline ÇÖHBÖ & Gruplar arası & 4.644 & 4 & 1.161 & 5.786 & $\mathbf{. 0 0 0}$ & A-D, A-E, B- \\
& Gruplar içi & 43.341 & 216 & .201 & & D, B-E, C-E \\
\cline { 2 - 7 } & Toplam & 47.985 & 220 & & & & \\
\hline \multirow{2}{*}{ EÖYMA } & Gruplar arası & 1.592 & 4 & .398 & 3.105 & $\mathbf{. 0 1 6}$ & A-E, B-E \\
& Gruplar içi & 27.682 & 216 & .128 & & & \\
\cline { 2 - 7 } & Toplam & 29.273 & 220 & & & \\
\hline
\end{tabular}

Not. A: 1 yıldan az, B: 1-3 yı1, C: 4-6 y11, D: 7-9 yı1, E: 10 yıldan fazla

Tablo 7 incelendiğinde, öğrencilerin ÇÖHBÖ puan ortalamalarının bilgisayar kullanma sürelerine göre istatistiksel olarak anlamlı farklılık gösterdiği görülebilir, $\mathrm{F}(4,216)=5.786$, p<.05. Benzer şekilde öğrencilerin EÖYMA puan ortalamalarının da bilgisayar kullanma süresine göre istatistiksel olarak anlamlı farklılık gösterdiği görülebilir, $\mathrm{F}(4,216)=3.105, \mathrm{p}<.05$. Yapılan post hoc testlerden Scheffe ve Dunnett's C testleri sonuçlarına göre bilgisayar kullanma süresi 1 yıldan az olan öğrenciler ile bilgisayar kullanma süresi 7-9 yıl öğrencilerin, bilgisayar kullanma süresi 1 yıldan az olan öğrenciler ile 10 yıldan fazla olan öğrencilerin, bilgisayar kullanma süresi 1-3 yıl olan öğrenciler ile 7-9 yıl olan öğrencilerin, bilgisayar kullanma süresi 1-3 yıl olan öğrenciler ile 10 yıldan fazla olan öğrencilerin ve bilgisayar kullanma süresi 4-6 y1l olan öğrenciler ile 10 yıldan fazla olan öğrencilerin ÇÖHBÖ puan ortalamaları arasında anlamlı farklılık olduğu görülmüştür. Benzer şekilde bilgisayar kullanma süresi 1 yıldan az olan öğrenciler ile 10 yıldan fazla olan öğrencilerin ve bilgisayar kullanma süresi 1-3 yıl olan öğrenciler ile 9 yıldan fazla olan öğrencilerin EÖYMA puan ortalamaları arasında anlamlı farklılık olduğu görülmüştür.

Öğrencilerin internet kullanma sürelerine göre ÇÖHBÖ ve EÖYMA puanlarında gözlenen farklılığının istatistiksel olarak anlamlılığını test etmek amacıyla yapılan ANOVA sonucunda ulaşılan bulgular Tablo 8'de verilmiştir.

Tablo 8: ÇÖHBÖ ve EÖYMA Puanlarının İnternet Kullanma Süresine göre ANOVA Sonuçları

\begin{tabular}{llccccc}
\hline Ölçekler & & Kareler Toplamı & sd & Kareler Ortalaması & F & p \\
\hline ÇÖHBÖ & Gruplar arası & .124 & 2 & .062 & .282 & .755 \\
& Gruplar içi & 47.861 & 218 & .220 & & \\
& Toplam & 47.985 & 220 & & .056 & .659 \\
\hline EÖYMA & Gruplar arası & .112 & 2 & .134 & \\
& Gruplar içi & 29.162 & 218 & & \\
& Toplam & 29.273 & 220 & & & \\
\hline
\end{tabular}

Tablo 8 incelendiğinde, öğrencilerin ÇÖHBÖ puan ortalamalarının internet kullanma sürelerine göre istatistiksel olarak anlamlı bir farklılık göstermediği görülebilir, $F(2,218)=.282$, $\mathrm{p}>.05$. Aynı şekilde öğrencilerin EÖYMA puan ortalamalarının da internet kullanma sürelerine göre istatistiksel olarak anlamlı bir farklılık göstermediği ifade edilebilir, $F(2,218)=.417, p>.05$ (Büyüköztürk, 2020).

Öğrencilerin uzaktan eğitim sisteminde geçirdikleri sürelere göre ÇÖHBÖ ve EÖYMA puanlarında gözlenen farklılığın istatistiksel olarak anlamlılığını ortaya çıkarmak amacıyla yapılan ANOVA sonucunda ulaşılan bulgular Tablo 9' da verilmiştir. 
Tablo 9: ÇÖHBÖ ve EÖYMA Puanlarının Uzaktan Eğitim Sisteminde Geçirilen Süreye göre ANOVA Sonuçları

\begin{tabular}{llcccccc} 
Ölçekler & & Kareler Toplamı & sd & Kareler Ortalamas1 & F & p & Anlamlı fark \\
\hline ÇÖHÖ & Gruplar aras1 & 4.679 & 3 & 1.560 & 7.815 & $\mathbf{. 0 0 0}$ & A-B, A-C, A- \\
& Gruplar içi & 43.306 & 217 & .200 & & & D, B-C \\
\cline { 2 - 7 } & Toplam & 47.985 & 220 & & & & \\
\hline EÖYMA & Gruplar arası & 2.266 & 3 & .755 & 6.068 & $\mathbf{. 0 0 1}$ & A-B, A-C \\
& Gruplar içi & 27.008 & 217 & .124 & & & \\
\cline { 2 - 4 } & 29.273 & 220 & & & & \\
\hline
\end{tabular}

Not. A: 1 saatten az, B: 1-3 saat, C: 4-6 saat, D: 7 saatten fazla

Tablo 9 incelendiğinde, öğrencilerin ÇÖHBÖ puan ortalamalarının uzaktan eğitim sisteminde geçirdikleri sürelere göre istatistiksel olarak anlamlı farklılık olduğu görülebilir, $\mathrm{F}(3,217)=7.851, \mathrm{p}<.05$. Benzer şekilde öğrencilerin EÖYMA puan ortalamalarının da uzaktan eğitim sisteminde geçirdikleri sürelere göre istatistiksel olarak anlamlı farklılık olduğu görülebilir, $\mathrm{F}((3,217)=6.068, \mathrm{p}<.05$. Yapılan post hoc testlerden Scheffe ve Dunnett's C testleri sonuçlarına göre, uzaktan eğitim sisteminde geçirdiği süre 1 saatten az olan öğrenciler ile 1-3 saat arasında olan öğrencilerin, uzaktan eğitim sisteminde geçirdiği süre 1 saatten az olan öğrenciler ile 4-6 saat arasında olan öğrencilerin, uzaktan eğitim sisteminde geçirdiği süre 1 saatten az olan öğrenciler ile 7 saatten fazla olan öğrencilerin ve uzaktan eğitim sisteminde geçirdiği süre 1-3 saat arası olan öğrenciler ile 4-6 saat arasında olan öğrencilerin ÇÖHBÖ puan ortalamaları arasında anlamlı farklılık olduğu görülmüsşür. Benzer şekilde uzaktan eğitim sisteminde geçirdiği süre 1 saatten az olan öğrenciler ile 1-3 saat arasında olan öğrencilerin, uzaktan eğitim sisteminde geçirdiği süre 1 saatten az olan öğrenciler ile 4-6 saat arasında olan öğrencilerin EÖYMA puan ortalamaları arasında anlamlı farklılık olduğu görülmüştür.

Araştırmanın üçüncü alt problemi olan "Pandemi sürecinde öğrencilerin çevrimiçi öğrenme hazır bulunuşluk ve e-öğrenme ortamlarına yönelik motivasyon düzeyleri arasında anlamlı bir ilişki var mıdır?" sorusunun yanıtı için ÇÖHBÖ puanları ile EÖYMA puanları arasındaki Pearson korelasyon katsayısına bakılmıştır. Korelasyon analizi ile ulaşılan bulgular Tablo 10'da verilmiştir.

Tablo 10: ÇÖHBÖ Puanları ve EÖYMA Puanları Arasındaki Korelasyon Analizi Sonuçları

\begin{tabular}{lccc}
\hline Değişkenler & $\mathrm{N}$ & $\mathrm{p}$ & $\mathrm{r}$ \\
\hline ÇÖHBÖ puanı* EÖOMA puanı & 221 & .000 & .487 \\
\hline
\end{tabular}

Tablo 10 incelendiğinde, EÖYMA puanları ile ÇÖHBÖ puanlarının pozitif yönlü orta düzeyde ve anlamlı bir şekilde ilişkili olduğu görülebilir, $\mathrm{r}=.487, \mathrm{p}<.05$. Determinasyon katsayısı $\left(r^{2}=.2371\right)$ göz önüne alındığında, çevrimiçi öğrenme hazır bulunuşluğundaki değişimin \%24'ünün e-öğrenme ortamlarına yönelik motivasyon düzeyinden kaynaklandığı söylenebilir ya da e-öğrenme ortamlarına yönelik motivasyon düzeyindeki değişkenliğin \%24'ünün çevrimiçi öğrenme hazır bulunuşluğundan kaynaklandığı ifade edilebilir (Büyüköztürk, 2020).

\section{Tartışma, Sonuç ve Öneriler}

Etkili çevrimiçi öğrenmeye nasıl ulaşılacağını daha iyi anlamak için etken olan unsurların doğru tespit edilmesi oldukça önemli görülmektedir. Örneğin çevrimiçi öğrenmeye yönelik hazır bulunuşluluk ve motivasyon bu unsurlardandır (Yıldırım, 2012; Yurdugül ve Alsancak Sırakaya, 2013). Bunun yanında araştırmalarda teknik becerilerin, öğrencilerin web tabanlı öğrenme ortamlarındaki performansıyla ilişkili olduğu belirtilirken (Peng, Tsai ve Wu, 2006), öğrencilerin internet algılarının ve tutumlarının çevrimiçi öğrenme ortamına ilişkin süreci şekillendirdiği ortaya konulmaktadır (Tsai ve Lin, 2004). Sun ve diğerleri (2008) "sistem kalitesi, içerik kalitesi, hizmet kalitesi, öğreticilerin tutumu, öğrencilerin bakış açısı ve destekleyici konular" gibi faktörlerin eöğrenme süreci üzerinde olumlu etkisi olduğunu belirtmiştir. Bu faktörler, insan faktörleri ve teknoloji faktörleri olmak üzere iki kategoriye ayrılmaktadır (Nguyen ve Huynh, 2020). İnsan 
faktörleri, öğrencilerin tutumları, hazır bulunuşlukları, kendi öğrenim süreçlerini düzenlemeleri ve yönetmeleri, öz üretkenlikleri (Özkan ve Köseler, 2009), kendilerine güvenleri (Passerini ve Granger, 2000), öğretmenlerin tutumları, katkıları ve motivasyon destekleri (Kim ve diğerleri, 2012) gibi unsurları kapsamaktadır. COVID-19 pandemi sürecinde uzaktan eğitime katılmak zorunda kalan ve sosyal ortamından kopan öğrenciler karşımıza çıkmaktadır ve bu örneklem grupları pandemi öncesi yapılan uzaktan eğitime etki eden faktörlere ilişkin çalışmalardaki örneklem gruplarından farklıdır. Pandemi sürecinde ülkemizde üniversitelerde geçilmek zorunda kalınan uzaktan eğitimde, eğitimöğretim çevrimiçi veya çevrimdışı çeşitli içeriklerle yürütülmeye çalışılmaktadır. Fakat sadece teknik alt yapı ve içerik yeterli değildir. Çünkü çevrimiçi dersler içerik ve materyal açısından zengin, iyi tasarlanmış olsa da, öğrencilerin bakış açıları, tutumları ve motivasyonları uygun değilse, eöğrenme başarılı olmamaktadır (Passerini ve Granger, 2000). Çevrimiçi öğrenme ortamında öğretmen ve öğrencilerin ne kadar hazır oldukları önemli bir unsurdur. Bu nedenle e-öğrenme başarısını doğrudan etkileyen insan faktörü unsurlarından hazır bulunuşluk ve motivasyonun pandemi sürecinde incelenmesi, sürecin uzaması veya kalıcı hale gelmesi durumunda e-öğrenmenin başarılı bir şekilde yürütülmesi için planlama yapılmasına yardımcı olabilir. Hazır bulunuşluk ve motivasyon düzeyleri arasındaki ilişkinin ortaya konulmasının uzaktan eğitim ortamında öğrenim görmekte olan öğrencilerin öğretimlerinin verimli ve başarılı olması için bu değişkenlere ilişkin düzenleme yapılmasını kolaylaştırabilir. Buna göre bu araştırma kapsamında pandemi sürecinde eğitim fakültesi öğrencilerinin çevrimiçi öğrenme hazır bulunuşlukları ve e-öğrenme ortamlarına yönelik motivasyon düzeyleri farklı değişkenlere göre incelenip karşılaştırılmış ve öğrencilerin çevrimiçi öğrenme hazır bulunuşlukları ile e-öğrenme ortamlarına yönelik motivasyon düzeyleri arasındaki ilişki incelenmiştir.

Pandemi sürecinde eğitim fakültesi öğrencilerinin çevrimiçi öğrenme hazır bulunuşluk düzeylerinin yüksek olduğu, e-öğrenme ortamlarına yönelik motivasyon düzeylerinin orta düzeyde olduğu belirlenmiştir. Elde edilen bu sonuç Çobanoğlu ve diğerleri (2017) ile Özgür ve diğerleri (2014) tarafından yapılmış olan çalışmaların sonuçlarıyla benzerlik göstermektedir. Benzer şekilde öğrencilerin e-öğrenme ortamlarına yönelik motivasyon düzeylerinin incelendiği bir çalışmada öğrencilerin motivasyon düzeyinin "kararsızım" düzeyinde olduğu sonucuna ulaşılmıştır (Yıldırım ve Şahin, 2015). Buna göre pandemi sürecinde eğitim fakültesi öğrencilerinin sahip olduğu çevrim öğrenme hazır bulunuşluluk düzeyleri ve motivasyon düzeyleri ile pandemi öncesi yapılan çalışmaların sonuçlarının benzer olduğu belirtilebilir. COVID-19 pandemi sürecinde uzaktan eğitime geçmek zorunda kalan ve sosyal ortamından kopan eğitim fakültesi öğrencilerinin çevrimiçi öğrenme hazır bulunuşluklarının ve e-öğrenme ortamlarına yönelik motivasyon düzeylerinin pandemi öncesi çalışmalarda elde edilen sonuçlarla benzerlik göstermiş olması araştırmaya katılan öğrenci grubunun özelliğinden kaynaklanıyor olabilir. Bu nedenle pandemi döneminde öğrencilerin çevrimiçi öğrenme hazır bulunuşluk ve e-öğrenme ortamlarına yönelik motivasyon düzeylerinin belirlenmesi konusunda farklı araştırmaların yapılması gerektiği ifade edilebilir.

Çalışmada pandemi sürecinde eğitim fakültesi öğrencilerinin çevrimiçi öğrenme hazır bulunuşluk ve e-öğrenme ortamlarına yönelik motivasyon düzeylerinin cinsiyetlerine göre anlamlı bir farklılık göstermediği sonucuna ulaşılmıştır. Çakır ve Horzum (2015), Ibrahim ve diğerleri (2002), Özgür ve diğerleri (2014), Yakın ve Tınmaz (2013) tarafından yapılan çalışmalarda elde edilen sonuçlarda da çevrimiçi öğrenme hazır bulunuşluk düzeylerinin öğrencilerin cinsiyetlerine göre farklılaşmadığı görülmüştür. Aynı şekilde e-öğrenme ortamlarına yönelik motivasyon düzeylerinin öğrencilerin cinsiyetlerine göre farklılaşmadığı sonucu Bertiz (2018) tarafından yapılan çalışma ile benzerlik göstermektedir. Araştırmada pandemi sürecinde eğitim fakültesi öğrencilerinin çevrimiçi öğrenme hazır bulunuşluk ve e-öğrenme ortamlarına yönelik motivasyon düzeylerinde sınıf düzeyine göre farklılık olmadığı görülmüştür. Elde edilen bu sonuç Sarıtaş ve Barutçu (2020) ile Yurdugül ve Demir (2017) tarafından yapılan çalışmalarda ulaşılan sonuçlarla ile benzerlik göstermemiştir. Benzer şekilde e-öğrenme ortamlarına yönelik motivasyon düzeylerinin öğrencilerin 
sınıf düzeylerine göre farklılaşmadığına ilişkin sonuç ise Demir (2008) tarafından yapılan çalışmada ulaşılan sonuçlarla ile benzerlik göstermemektedir. Buna göre çevrimiçi öğrenme hazır bulunuşluk ve e-öğrenme ortamlarına yönelik motivasyon düzeylerinin sınıf düzeyine göre farklılaşıp farklılaşmadığı konusunda farklı araştırmaların yapılması gerektiği ifade edilebilir.

Pandemi sürecinde eğitim fakültesi öğrencilerinin çevrimiçi öğrenme hazır bulunuşluk ve eöğrenme ortamlarına yönelik motivasyon düzeylerinin bilgisayar kullanma sürelerine göre farklılık olduğu görülmüştür. Bertiz (2018) tarafından yapılan çalışmada ise elde edilen bu sonuçtan farklı olarak e-öğrenme ortamlarına yönelik motivasyon düzeylerinde bilgisayar kullanma süresine göre farklılık olmadığ 1 sonucuna ulaşılmıştır. Bu iki sonuç arasındaki farkın örneklem grubundaki öğrencilerin eğitim düzeylerinin farklı olmasından kaynaklandığı düşünülmektedir. Ayrıca öğrencilerin çevrimiçi öğrenme hazır bulunuşluklarının internet erişimine sahip olma durumlarına göre farklılaşmadığı görülürken, e-öğrenme ortamlarına yönelik motivasyon düzeylerinin internet erişimine sahip olma durumlarına göre farklılaştı̆g görülmüştür. Çevrimiçi öğrenme hazır bulunuşluk düzeylerinin öğrencilerin internet erişimine sahip olma durumuna göre farklılaşmadığ sonucu Ibrahim ve diğerleri (2002) tarafindan yapılan çalışmada ulaşılan sonuç ile benzerlik göstermiştir. Buna göre öğrencilerin internet erişimine sahip olmasının e-öğrenme ortamlarına yönelik motivasyonlarını artırdığı, dolayısı ile pandemi sürecinde uzaktan eğitime geçmek zorunda kalan öğrencilerin derslere yönelik motivasyonlarının artırılması için öğrencilerin tümüne internet erişimi sağlanması gerektiği sonucu çıkarılabilir.

Pandemi sürecinde bilgisayara sahip olma durumunun öğrencilerin çevrimiçi öğrenme hazır bulunuşluklarında farklılık yaratmadığı sonucuna ulaşılmıştır. Bu sonuç Ibrahim ve diğerleri (2002) tarafından yapılan çalışmanın sonucu ile örtüşmektedir. Bilgisayara sahip olma durumu farklı olan öğrencilerin e-öğrenme ortamlarına yönelik motivasyon düzeyleri arasında farklılık olduğu görülmüştür. Bu sonuç, öğrencilerin e-öğrenme ortamların yönelik motivasyonlarının artırılması için öğrencilere bilgisayara sahip olma olanağı verilmesi gerektiği şeklinde yorumlanabilir. Çalışmada pandemi sürecinde eğitim fakültesi öğrencilerinin çevrimiçi öğrenme hazır bulunuşluk ve e-öğrenme ortamlarına yönelik motivasyon düzeylerinin internet kullanma sürelerine göre farklılaşmadığı görülmüştür. Alsancak Sırakaya ve Yurdugül (2016), Çatana Kuleli (2018), Özgür ve diğerleri (2014) tarafından yapılan çalışmalarda da benzer sonuçlar elde edilmiştir. E-öğrenme ortamlarına yönelik motivasyon düzeylerinin öğrencilerin internet kullanma süresine göre farklılaşmadığ 1 sonucu Bertiz (2018) tarafından yapılan çalışmada elde edilen sonuç ile benzerlik göstermektedir. Buna göre internet kullanma süresinin çevrimiçi öğrenme hazır bulunuşluk ve e-öğrenme ortamlarına yönelik motivasyon düzeylerine etkisinin olmadığı ifade edilebilir.

Eğitim fakültesi öğrencilerinin çevrimiçi öğrenme hazır bulunuşluk ve e-öğrenme ortamlarına yönelik motivasyon düzeylerinin, çevrimiçi ve çevrimdışı derse katılma durumlarına göre farklılaşıp farklılaşmadığına yönelik olarak yapılan incelemede çevrimiçi derse katılan ve katılmayan öğrencilerin çevrimiçi öğrenme hazır bulunuşluk puanları arasında farklılık olmadığı görülürken, e-öğrenme ortamlarına yönelik motivasyon puanları arasında farklılık olduğu görülmüştür. Çatana Kuleli (2018) tarafından yapılan çalışmada öğretmen adaylarının çevrimiçi veya çevrimdışı derse katılmasının çevrimiçi öğrenme hazır bulunuşlukları üzerinde bir etkisi olmadığı sonucuna ulaşılmıştır ve bu sonuç çalışmadan elde edilen bulgularla örtüşmektedir. Bertiz (2018) tarafından yapılan çalışmada uzaktan eğitim alıp almama durumuna göre e-öğrenme ortamlarına yönelik motivasyon arasında anlamlı bir ilişki bulunmamıştır. Ancak bu bulgunun çalışmada kullanılan örneklem özelliklerinden kaynaklandığı ve öğrencilerin daha önce uzaktan eğitim alıp almamasının (hazır bulunuşluklarının) motivasyon düzeylerini etkileyebileceği ifade edilmiştir. Çevrimiçi derse katılan öğrencilerin e-öğrenme ortamlarına yönelik motivasyon düzeylerinin daha yüksek çıkmış olması sonucu, pandemi döneminde uzaktan eğitime katılmak zorunda kalan öğrencilerin derslere yönelik motivasyonlarının artırılması için çevrimiçi dersler yapılması gerektiği şeklinde yorumlanabilir. Uzaktan eğitim sisteminde geçirilen süreye göre çevrimiçi öğrenme hazır 
bulunuşluk ve e-öğrenme ortamlarına yönelik motivasyon puanlarının farklılaştığı görülmüş ve bu bulgu, Bertiz (2018) ile İbicioğlu ve Antalyalı (2005)'nın yapmış oldukları çalışmalarda elde edilen uzaktan eğitim sisteminde geçirilen sürenin motivasyonla ilişkili olduğu bulgusu ile benzerlik göstermektedir. Buna göre, öğrencilerin uzaktan eğitim sisteminde geçirdikleri sürenin, e-öğrenme ortamlarına yönelik motivasyon düzeylerini etkilediği göz önünde bulundurularak düzenlemeler yapılması gerektiği ifade edilebilir.

Çalışmada incelenlerden biri de pandemi sürecinde eğitim fakültesi öğrencilerinin eöğrenme ortamlarına yönelik motivasyon düzeyleri ile çevrimiçi öğrenme hazır bulunuşlukları arasındaki ilişkidir. Bu değişkeler arasında pozitif yönlü orta düzeyde ve anlamlı bir ilişki olduğu bulunmuştur. Bu bulguya dayanarak araştırmanın yapıldığı örneklem için çevrimiçi öğrenme hazır bulunuşluğu yüksek düzeyde olanların e-öğrenme ortamlarına yönelik motivasyon düzeylerinin de yüksek olduğu yorumu yapılabilir. Hasani ve diğerleri (2020) tarafından yapılan çalışmada ise bu çalışmada elde edilen sonuçtan farklı olarak motivasyonun algılanan uzaktan eğitim hazır bulunuşluğunu pozitif yönde etkilemediği tespit edilmiştir. Buna göre motivasyon ile hazır bulunuşluk ilişkisini belirlemeye yönelik olarak farklı araştırmalar yapılması gerektiği ifade edilebilir.

Pandemi sürecinde eğitim fakültesi öğrencilerinin çevrimiçi öğrenme hazır bulunuşluk düzeylerini ölçmek için ÇÖHBÖ ve e-öğrenme ortamlarına yönelik motivasyon düzeylerini ölçmek için EÖYMA kullanılmıştır. Kullanılan bu ölçme araçları dışında alanyazında farklı ölçme araçları da mevcuttur. Çalışma, farklı ölçme araçları veya nitel yöntemlerle desteklenerek farklı öğrenci gruplarında yenilenebilir. Çalışmanın örneklemini pandemi sürecinde eğitim fakültesi öğrencileri oluşturmaktadır. Çalışma farklı fakülte öğrencileri veya farklı eğitim kademelerinde öğrenim gören öğrencilerle gerçekleştirilerek aradaki ilişki incelenebilir. Farklı çalışmalarda eğitim fakültesi öğrencilerinin çevrimiçi öğrenme hazır bulunuşluğu ve e-öğrenme ortamlarına yönelik motivasyonu ile farklı değişkenlerin ilişkisi incelenebilir. Hem öğreticilerin hem de öğrencilerin COVID-19 salgınının yayılması boyunca yeni bir e-öğrenme ortamına uyum sağlamaları zaman alan bir süreçtir. Yeni bir öğrenme ortamına adapte olmayı gerektiren bu süreçte başarının sağlanması için öğrencilerin motivasyonunun yüksek tutulması önemli görülmektedir. Çalışma sonucunda öğrencilerin motivasyonlarının düşük olmasa da kararsız seviyede çıkmış olması önemlidir. Ayrıca hazır bulunuşluk ile motivasyonun pozitif yönde ilişkili olduğunun tespiti de uzaktan eğitimin verimliliği ve başarısını etkileyecek insani faktörlerin üzerinde durulması gerektiğini göstermektedir. Yeni öğrenme ortamlarını keşfetmek ve bunlara uyum sağlamak için daha fazla motivasyonunun gerektiği bilinmektedir (Nguyen ve Huynh, 2020). Bu nedenle e-öğrenme ortamlarının içerikleri geliştirilirken hazır bulunuşluk ve motivasyon gibi faktörlerin önceden tespit edilmesi, öğrencilerin e-öğrenme sürecinde verimliliklerini, konsantrasyonlarını ve etkililiklerini artırmak için faydalı olabilir.

Öğrencilerin uzaktan eğitim veya e-öğrenmeyi benimsemesini etkileyen faktörler konusunda yapılan çeşitli çalışmalar kapsamında çeşitli başlıkların belirlendiği görülmektedir. Bunlar kurum kültürü, sosyal etkileşim, akademik beceriler, teknik beceriler, öğrenci motivasyonu, zaman ve destek, maliyet ve internet erişimi, teknik sorunlar, bir yaklaşım olarak e-öğrenmenin doğası, teknoloji kullanımı ve zaman olarak sıralanırken öğrenciler açısından ise motivasyon, öz yeterlilik, hazır bulunuşluluk, öz-yönelimli öğrenme becerileri ve e-öğrenmenin konforu olarak sıralanmaktadır (Becker ve diğerleri, 2013; Hasani ve diğerleri, 2020; Muilenberg ve Berge, 2005). Bu araştırmada elde edilen bulgular, COVID-19 pandemisi nedeniyle aniden geçilen uzaktan eğitim sürecinde öğrencilerin e-öğrenmeyi benimsemelerinde önemli rol oynadığı düşünülen hazır bulunuşluluk ve motivasyon konularında önemli sonuçların elde edilmesini sağlamıştır. Diğer yandan öğrencilerin uzaktan eğitime yönelik hazır bulunuşluklarında önemli rol oynadığı Hasani ve diğerleri (2020) tarafından belirtilen öğrenci öz yeterlilikleri, e-öğrenmede konfor, belirsizlikten kaçınma, finansal 
yetenekler ve teknolojinin kullanılabilirliği faktörleri ile ilgili çalışmalar yapılması gerektiği ifade edilebilir.

Gelecekteki çalışmalarda uzaktan eğitimin verimliği ve başarısının artırılması için önemli faktörler olduğu düşünülen öğrencilerin hazır bulunuşluğu ve motivasyonlarının yanı sıra bilgisayar kullanma öz yeterliklerinin de incelenmesi önerilebilir. Çünkü öğrencilerin çevrimiçi öğrenmede başarılı olmaları için temel veya orta düzeyde teknik yeterliliğe ihtiyaç bulunmaktadır. Uzaktan eğitime aniden geçmek zorunda kalan öğrenciler arasından çevrimiçi öğrenmeye en fazla adapte olan öğrencilerin sahip oldukları özelliklerin incelenmesi, gelecekte gerçekleştirilecek uzaktan eğitim uygulamalarının verimliliğini artırabilir.

Öğrenme etkinliği düzenlemelerinde çevrimiçi öğrenme ortamlarının daha fazla esnekliğe sahip olmaları sağlanarak, öğrencilerin, öğrenen kontrolü boyutunda daha fazla yer alması sağlanabilir. Pandemi sürecinde aniden adapte olunması gereken uzaktan eğitim, yaşamımızın bir parçası haline gelirken yüz yüze yapılanmayan eğitim nedeni ile uzaktan eğitimin başarısının artırılması ihtiyacı doğmuştur. Bu süreçte bilgisayar, internet kullanımı gibi çeşitli değişkenlerin yanında kuşkusuz çevrimiçi öğrenme sürecine yönelik hazır bulunuşluluk ve motivasyon, çevrimiçi öğrenme sürecini etkileyen önemli etmenler olarak karşımıza çıkmaktadır. Yapılan çalışmalar çevrimiçi öğrenme algılarının, çevrimiçi öğrenme hazır bulunuşluğu üzerinde önemli etkilerinin olduğunu ortaya koymaktadır (Smith ve diğerleri, 2003). Bir öğrencinin algıları ve motivasyonu ne kadar olumluysa, çevrimiçi öğrenmeye o kadar hazır olarak başlamaktadır. Bu kapsamda yapılan çalışmanın pandemi sürecinde çevrimiçi öğrenme uygulamalarının başarıya ulaşmasını sağlama açısından öğrenen özelliklerine 1şık tutuğu düşünülmektedir. Çalışmanın devamında öğrencilerin çevrimiçi öğrenme algılarının hazırbulunuşluk, motivasyon ve diğer faktörler açısından değerlendirilerek çevrimiçi öğrenme sürecinde motivasyonu yüksek tutarak performansı ve olumlu algıları arttırmak için farklı değişkenlerin incelenerek araştırmanın genişletilmesi önerilebilir.

Uzaktan eğitim sisteminde geçirilen süre ve bilgisayar kullanma süresi değişkenlerinin çevrimiçi öğrenme hazır bulunuşluğuna etkisine dair alanyazında bir bulguya rastlanmamıştır. Ayrıca alanyazında bilgisayara sahip olma durumu ve internet erişimine sahip olma durumu değişkenlerinin e-öğrenme ortamlarına yönelik motivasyon düzeyleri üzerine etkisinin incelendiği benzer bir çalışmaya da rastlanmamıştır. Farklı çalışmalarda eğitim fakültesi öğrencilerinin çevrimiçi öğrenme hazır bulunuşluğu ve e-öğrenme ortamlarına yönelik motivasyonu ile farklı değişkenlerin ilişkisi incelenebilir.

\section{Kaynaklar}

Akandere, M., Özyalvaç, N. T., \& Duman, S. (2010). Ortaöğretim öğrencilerinin beden eğitimi dersine yönelik tutumları ile akademik başarı motivasyonlarının incelenmesi (Konya Anadolu Lisesi örneği). Selçuk Üniversitesi Sosyal Bilimler Enstitüsü Dergisi, 24, 1-10. http://dergisosyalbil.selcuk.edu.tr/susbed/article/view/208

Akdemir, O. (2011). Yükseköğretimimizde uzaktan eğitim. Yükseköğretim ve Bilim Dergisi, 1(2), 69-71. http://dx.doi.org/10.5961/jhes.2011.011

Akıncı, A., \& Seferoğlu, S. S. (2010, 10-12 Şubat). Bilişim şuraları, teknoloji politikaları ve eğitim. M. Akgül, E. Derman, U. Çağlayan, A. Özgit, \& T. Yılmaz (Editörler), Akademik Bilişim'10 - XII. Akademik Bilişim Konferansı Bildirileri kitabı içerisinde (s. 475-482). Muğla, Türkiye. https://ab.org.tr/kitap/ab10.pdf

Alsancak Sırakaya, D., \& Yurdugül, H. (2016). Öğretmen adaylarının çevrimiçi öğrenme hazır bulunuşluluk düzeylerinin incelenmesi: Ahi Evran Üniversitesi örneği. Journal of Kirsehir 
Education Faculty, 17(1), 185-200. http://openaccess.ahievran.edu.tr/xmlui/handle/20.500. 12513/880\#sthash.e2o9x4WI.dpbs

Altıparmak, M., Kurt, İ. D., \& Kapıdere M. (2011, 2-4 Şubat). E-öğrenme ve uzaktan eğitimde açık kaynak kodlu öğrenme yönetim sitemleri. M. Akgül, E. Derman, A. Özgit, U. Çağlayan, M. Ertürkler, \& M. Karakaplan (Editörler), Akademik Bilişim'11 - XIII. Akademik Bilişim Konferansı Bildirileri kitabı içerisinde (s. 343-351). https://ab.org.tr/ab11/kitap/_AB11 _tek.pdf

Ateş Çobanoğlu, A., Uzunboylar, O., \& Altun, E. (2017). Çevrimiçi öğrenme hazır bulunuşluk, tutum ve algılanan çevrimiçi sosyalliğin işbirlikli harmanlanmış bir derste incelenmesi. Elektronik Sosyal Bilimler Dergisi, 16(63), 1218-1229. https://doi.org/10.17755/esosder.292310

Aydın, C. H. (2002, 23-25 Mayıs). Çevrimiçi (online) öğrenme toplulukları [Sözlü bildiri]. Anadolu Üniversitesi Açık Öğretim Fakültesi 1. Uluslararası Açık ve Uzaktan Eğitim Sempozyumu, Eskişehir, Türkiye.

Azizoğlu, N., \& Çetin, G. (2009). 6 ve 7. sınıf öğrencilerinin öğrenme stilleri, fen dersine yönelik tutumları ve motivasyonları arasındaki ilişki. Kastamonu Eğitim Dergisi, 17(1), 171-182. https://dergipark.org.tr/tr/download/article-file/817974

Becker, K., Newton, C. \& Sawang S. (2013). A learner perspective on barriers to e-learning. Australian Journal of Adult Learning, 53(2), 211-233. https://files.eric.ed.gov/fulltext/EJ1013664.pdf

Bertiz, Y. (2018). Farklı bilişsel esneklik düzeyine sahip öğrencilerin uzaktan eğitime karşı motivasyon düzeylerinin incelenmesi [Yayımlanmamış doktora tezi]. Gazi Üniversitesi.

Borotis, S. \& Poulymenakou, A. (2004). E-learning readiness components: Key issues to consider before adopting e-learning interventions. In J. Nall \& R. Robson (Eds.), Proceedings of ELearn 2004--World Conference on E-Learning in Corporate, Government, Healthcare, and Higher Education (pp. 1622-1629). Washington, DC, USA: Association for the Advancement of Computing in Education (AACE). https://www.learntechlib.org/primary/p/11555/.

Bozkurt, A. (2017). Türkiye'de uzaktan eğitimin dünü, bugünü ve yarını. Açıkögretim Uygulamaları ve Araştırmaları Dergisi, 3(2), 85-124. https://dergipark.org.tr/en/download/article-file/ 403827

Büyüköztürk, Ş. (2020). Sosyal bilimler için veri analizi el kitabı (27. baskı). Pegem A Yayınları.

Büyüköztürk, Ş., Kılıç Çakmak, E., Akgün, Ö.E., Karadeniz, Ş., \& Demirel, F. (2009). Bilimsel araştırma yöntemleri. Pegem A Yayınları.

Canbulat, T., \& Kırıktaş, H. (2016). İlkokula hazır bulunuşluk ölçeği’nin geliştirilmesi: Geçerlik ve güvenilirlik çalışması. Academia Eğitim Araştırmaları Dergisi, 1(1), 26-35. https:// dergipark.org.tr/tr/download/article-file/286341

Commission of the European Communities (2001). Communication from the commission to the council and the European parliament, the e-learning action plan, designing tomorrow's education. https://eur-lex.europa.eu/LexUriServ/LexUriServ.do?uri=COM:2001:0172:FIN: EN:PDF

Çakır, Ö., \& Horzum, M. (2015). Öğretmen adaylarının çevrimiçi öğrenmeye hazır bulunuşluk düzeylerinin çeşitli değişkenler açısından incelenmesi. Ĕgitimde Kuram ve Uygulama, 11(1), 1-15. https://dergipark.org.tr/tr/download/article-file/63458 
Çalışkan, Ş. (2019). Çevrimiçi ögrenme ortamının kullanılabilirlik analizi ve etkililiği: Ahmet Yesevi Üniversitesi örneği [Yayımlanmamış yüksek lisans tezi]. Necmettin Erbakan Üniversitesi.

Çatana Kuleli, S.(2018). Öğretmen adaylarının çevrimiçi öğrenmeye hazır bulunuşluk düzeyleri ve bilgi işlemsel düşünme becerilerinin değerlendirilmesi [Yayımlanmamış yüksek lisans tezi]. Düzce Üniversitesi.

Demir Kaymak, Z., \& Horzum, M. B. (2013). Çevrimiçi öğrenme öğrencilerinin çevrimiçi öğrenmeye hazır bulunuşluk düzeyleri, algıladıkları yapı ve etkileşim arasındaki ilişki. Kuram ve Uygulamada Eğitim Bilimleri, 13(3), 1783-1797. https://doi.org/10.12738/ estp.2013.3.1580

Demir, Z. (2008). Uzaktan eğitim ögrencilerinin akademik güdülenme düzeyleri (SAÜ Örneği) [Yayımlanmamış yüksek lisans tezi]. Sakarya Üniversitesi.

Düzakın, E., \& Yalçınkaya, S. (2008). Web tabanlı uzaktan eğitim sistemi ve Çukurova Üniversitesi öğretim elemanlarının yatkınlıkları. Çukurova Üniversitesi Sosyal Bilimler Enstitüsü Dergisi, 17(1), 225-244. https://dergipark.org.tr/tr/download/article-file/50421

Enfiyeci, T. (2019). Çevrimiçi ortamlarda uzaktan eğitim öğrencilerinin topluluk hissi motivasyon ve akademik başarısı arasındaki ilişki Ahmet Yesevi Üniversitesi örneği [Yayımlanmamış yüksek lisans tezi]. Gazi Üniversitesi.

Erfidan, A. (2019). Derslerin uzaktan ĕgitim yoluyla verilmesiyle ilgili ögretim elemanı ve öğrenci görüşleri Balıkesir Üniversitesi örneği [Yayımlanmamış yüksek lisans tezi]. Balıkesir Üniversitesi.

Ergül, H. (2006). Çevrimiçi eğitimde akademik başarıyı etkileyen güdülenme yapıları. The Turkish Online Journal of Educational Technology, 5(1), 124-128. http://www.tojet.net/ articles/v5i1/5113.pdf

Gökdaş, İ., \& Kayri, M. (2005). E-öğrenme ve Türkiye açısından sorunlar, çözüm önerileri. Yüzüncü Yll Üniversitesi Eğitim Fakültesi Dergisi, 2(2), 1-20. http://efdergi.yyu.edu.tr/ makaleler/cilt_II/ozetler/ig_mkayri.htm

Gülbahar, Y. (2012). E-Öğrenme. Pegem A Yayınları.

Gümüş, S. (2007). Çevrimiçi işbirliği ekiplerinde öğrenenlerin sorun çözerek öğrenmeyle ilgili tutum ve görüşleri [Yayımlanmamış yüksek lisans tezi]. Anadolu Üniversitesi.

Hasani, L. M., Adnan, H. R., Sensuse, D. I., Kautsarina, K., \& Suryono, R. R. (2020). Factors affecting student's perceived readiness on abrupt distance learning adoption: Indonesian higher-education perspectives. Research Gate (preprint). https://doi.org/10.13140/RG.2.2.22908.16008

Horton, W. (2006). E-learning by design. Pfeiffer.

Hung, M. L., Chou, C., Chen, C. H., \& Own, Z. Y. (2010). Learner readiness for online learning: Scale development and student perceptions. Computers \& Education, 55(3), 1080-1090. https://doi.org/10.1016/j.compedu.2010.05.004

Ibrahim, D. Z., Silong, A. D., \& Samah, B. A. (2002, 21-23 Şubat). Readiness and attitude towards online learning among virtual students [Sözlü bildiri]. $15^{\text {th }}$ Annual Conference of the Asian Association of Open Universities, Nueva Delhi, India. http://library.oum.edu.my/oumlib/sites/default/files/file_attachments/odlresources/4390/readiness.pdf 
İbicioğlu, H., \& Antalyalı, U. Ö. L. (2005). Uzaktan eğitimin başarısında imkân algı motivasyon ve etkileşim faktörlerinin etkileri: karş1laştırmalı bir uygulama. Çukurova Üniversitesi Sosyal Bilimler Enstitüsü Dergisi, 14(2), 325-338. https://dergipark.org.tr/tr/download/articlefile $/ 50240$

İşman, A. (2005). Uzaktan Eğitim (Genişletilmiş 2. baskı). Pegem A Yayınları.

Karataş, S., \& Üstündağ, M. T. (2008). Gazi Üniversitesi uzaktan eğitim programı öğrencilerinin internet temelli uzaktan eğitim doyumları ile demografik özellikleri arasındaki ilişki. Yüzüncü Yll Üniversitesi Eğitim Fakültesi Dergisi, 5(2), 62-73. https://dergipark.org.tr/tr/download/article-file/146333

Kaya, M. F. (2013). Coğrafya öğrenmeye yönelik motivasyon ölçeği geliştirme çalışması. Doğu Coğrafya Dergisi, 18(30), 155-173. https://dergipark.org.tr/en/download/article-file/27022

Kaya, Z. (2002). Uzaktan Ë̆itim. Pegem A Yayınları. http://www.jret.org/FileUpload/ds217232/File/uzaktanegitim.pdf

Khan, I. M. (2009). An analysis of the motivational factors in online learning [Doktora tezi, University of Phoenix]. https://www.learntechlib.org/p/127822/

Kim, K. J. (2005). Adult learners' motivation in self-directed e-learning[Doktora tezi, Indiana University]. https://scholarworks.iu.edu/dspace/bitstream/handle/2022/7107/umi-indiana1145.pdf? sequence $=1$ \&isAllowed $=\mathrm{y}$

Kim, K., Trimi, S., Park, H., \& Rhee, S. (2012). The impact of CMS quality on the outcomes of elearning systems in higher education: an empirical study. Decision Sciences Journal of Innovative Education, 10(4), 575-587. https://doi.org/10.1111/j.1540-4609.2012.00360.x

Koçdar, S. (2011). Uzman görüşlerine göre Türkiye'de uzaktan eğitim programlarının akreditasyonu[Yayımlanmamış doktora tezi]. Anadolu Üniversitesi.

Korkmaz, Ö., Çakır, R., \& Tan, S. S. (2015). Öğrencilerin e-öğrenmeye hazır bulunuşluk ve memnuniyet düzeylerinin akademik başarıya etkisi. Ahi Evran Üniversitesi Kırşehir Eğitim Fakültesi Dergisi, 16(3), 219-241. http://kefad2.ahievran.edu.tr/archieve/pdfler/Cilt16Sayi3/JKEF_16_3_2015_219-241.pdf

Kör, H., Çataloğlu, E., \& Erbay, H. (2013). Uzaktan ve örgün eğitimin öğrenci başarısı üzerine etkisinin araştırılması. Gaziantep Üniversitesi Sosyal Bilimler Dergisi, 12(2), 267-279. https://dergipark.org.tr/en/download/article-file/223274

Maugis, V., Choucri, N., Madnick, S., Siegel, M., Gillet, S., Haghseta, F., Zhu, H., \& Best, M. (2003). Global E-Readiness - For What? https://www.researchgate.net/publication/228940912_Global_e-Readiness-For_What

Muilenberg L. Y. \& Berge D. L. (2005). Student barriers to online learning: A factor analytic study. Distance Education, 26(1), 29-48. https://doi.org/10.1080/01587910500081269

Mutlu, M. E., Dinçer, G. D., Okur, M. R., \& Şişman, S. (2004, 11-13 Şubat). E-Öğrenme sistemlerinin tasarımında kavram haritalart, ögrenme nesneleri ve eğitim yönetim sistemlerinin rolü [Sözlü bildiri]. Akademik Bilişim 04 - VI. Akademik Bilişim Konferans1, Trabzon, Türkiye

Nguyen, T., \& Huynh, N. (2020). Impact of the COVID-19 pandemic outbreak on the learning process [Lisans tezi, Lapland University]. https://www.theseus.fi/handle/10024/340971 
Özan, M. B., Türkoğlu, A. Z., \& Şener, G. (2010). Okul yöneticilerinin sergiledikleri demokratik tutum ve davranışlarının öğretmenlerin motivasyonuna etkisi. Fırat Üniversitesi Sosyal Bilimler Dergisi, 20(1), 275-294. https://dergipark.org.tr/tr/download/article-file/715918

Özcan, S. (2019). Uzaktan eğitim veren kurumlarda öğretim elemanlarının çevrimiçi öğretime bağllı̆ğının incelenmesi [Yayımlanmamış doktora tezi]. Gazi Üniversitesi.

Özgür, H., Çuhadar, C. \& Akgün, F. (2014, Mayıs). Öğretmen adaylarının çevrimiçi ögrenmeye hazır bulunuşluk düzeylerinin incelenmesi [Sözlü bildiri]. $2^{\text {nd }}$ International Instructional Technologies Teacher Education Symposium, Afyonkarahisar, Türkiye.

Özkan, S., \& Köseler, R. (2009). Multi-dimensional students' evaluation of e-learning systems in the higher education context: An empirical investigation. Computers \& Education, 53(4), 12851296. https://doi.org/10.1016/j.compedu.2009.06.011

Özkaraca, O. (2005). Internet tabanlı güç elektroniği eğitimi [Yayımlanmamış yüksek lisans tezi]. Gazi Üniversitesi.

Passerini, K., \& Granger, M. J. (2000). A developmental model for distance learning using the Internet. Computers \& Education, 34(1), 1-15. https://doi.org/10.1016/S03601315(99)00024-X

Peng, H., Tsai, C. C., \& Wu, Y. T. (2006). University students' self-efficacy and their attitudes toward the Internet: The role of students' perceptions of the Internet. Educational Studies, 32(1), 73-86. https://doi.org/10.1080/03055690500416025

Polat, A., \& İşman, A. (2013, 12-14 Mart). Uzaktan eğitimde motivasyon. M. Elmas, A. İşman, D. Franklin, T. Franklin, \& A. Eskicumalı (Editörler), ICQH 2013, International Conference on Quality in Higher Education Proceedings Book içerisinde (s. 1074-1079). Sakarya, Türkiye. http://www.icqh.net/publication_folder/icqh/icqh2013.pdf

Sakal, M. (2017). Çevrimiçi öğrenmede öğrencilerin hazır bulunuşluk düzeylerinin demografik özelliklerine göre incelenmesi. Sosyal ve Beşeri Bilimler Araştırmaları Dergisi, 18(39), 81102. https://dergipark.org.tr/tr/download/article-file/453771

Sarıtaş, E., \& Barutçu, S. (2020). Öğretimde dijital dönüşüm ve öğrencilerin çevrimiçi öğrenmeye hazır bulunuşluğu: Pandemi döneminde Pamukkale Üniversitesi öğrencileri üzerinde bir araştırma. Internet Uygulamaları ve Yönetimi Dergisi, 11(1), 5-22. https://doi.org/10.34231/iuyd.706397

Seven, M. A., \& Engin, A. O. (2008). Öğrenmeyi etkileyen faktörler. Atatürk Üniversitesi Sosyal Bilimler Enstitüsü Dergisi, 12(2), 189-212. https://dergipark.org.tr/tr/download/articlefile/32119

Smith, P. J., Murphy, K. L., \& Mahoney, S. E. (2003). Towards identifying factors underlying readiness for online learning: An exploratory study. Distance Education, 24(1), 57-67. https://doi.org/10.1080/01587910303043

Sop, A. (2016). Ebeveyn tutumları, davranıs problemleri ve okula hazır bulunuşluk arasındaki ilişkinin öz düzenlemenin aracılık etkisi ile incelenmesi [Yayımlanmamış doktora tezi]. Hacettepe Üniversitesi.

Sun, P. C., Tsai, R. J., Finger, G., Chen, Y. Y., \& Yeh, D. (2008). What drives a successful eLearning? An empirical investigation of the critical factors influencing learner satisfaction. Computers \& education, 50(4), 1183-1202. https://doi.org/10.1016/j.compedu.2006.11.007 
Süer, S. (2010). 6. sınıf Sosyal Bilgiler dersinde coğrafi kavramlar bakımından öğrencilerin hazır bulunuşluk düzeyleri ve bu kavramların geliştirilmesi [Yayımlanmamış yüksek lisans tezi]. Marmara Üniversitesi.

Tsai, C. C., \& Lin, C. C. (2004). Taiwanese adolescents' perceptions and attitudes regarding the Internet: exploring gender differences. Adolescence, 39(156), 725-734. https://pubmed.ncbi.nlm.nih.gov/15727410/

Tabachnick, B.G., \& Fidell, L.S. (2013). Using multivariate statistics (6. bask1). Pearson.

Tubaishat, A., \& Lansari, A. (2011). Are students ready to adopt e-learning? A preliminary ereadiness study of a university in the gulf region. International Journal of Information and Communication Technology Research, 1(5), 210-215. http://citeseerx.ist.psu.edu/viewdoc/download?doi=10.1.1.302.302\&rep=rep1\&type=pdf

Türk Dil Kurumu [TDK]. (2011). Türkçe sözliük. TDK Yayınları.

Usta, E. (2011a). The effect of web-based learning environments on attitudes of students regarding computer and internet. Procedia-Social and Behavioral Sciences, 28, 262-269. https://doi.org/10.1016/j.sbspro.2011.11.051

Usta, E. (2011b). The examination of online self-regulated learning skills in web-based learning environments in terms of different variables. TOJET: The Turkish Online Journal of Educational Technology, 10(3), 278-286. https://files.eric.ed.gov/fulltext/EJ944994.pdf

Uşun, S. (2006), Uzaktan eğitim. Nobel Yayın Dağıtım

Ünal, M., \& Özdemir, M. Ç. (2008). Eğitim fakültelerinde ortak ders olarak okutulan yabancı dil derslerinde öğrencilerin bilişsel hazır bulunuşluk düzeylerinin akademik başarıya etkisi. Ahi Evran Üniversitesi Kırşehir Eğitim Fakültesi Dergisi, 9(1), 13-22. http://kefad.ahievran.edu.tr/InstitutionArchiveFiles/f44778c7-ad4a-e711-80ef00224d68272d/d1a3a581-af4a-e711-80ef00224d68272d/Cilt9Sayi1/JKEF_9_1_2008_13_22.pdf

Verhagen, T., Feldberg, F., Hoff, B., Meents, S., \& Merikivi, J. (2012). Understanding users' motivations to engage in virtual worlds: A multipurpose model and empirical testing. Computers in Human Behavior, 28(2), 484-495. https://doi.org/10.1016/j.chb.2011.10.020

Warner, D., Christie, G., \& Choy, S. (1998). Readiness of VET clients for flexible delivery including on-line learning. Australian National Training Authority. https://www.voced.edu.au/content/ngv\%3A35337

Yakın, İ., \& Tınmaz, H. (2013, 23-25 Ocak). Uzaktan eğitimde önemli bir boyut: Öğretmen adaylarının e-hazır bulunuşlukları. M. Akgül, U. Çağlayan, E. Derman, A. Özgit, M. Topakc1, R. Uyar, O. Oral, Ş. Akbunar, T. F. Kasalak, E. Sezgin, F. Yücel, H. Akar, \& U. Ercan (Editörler), Akademik Bilişim 2013 - XV. Akademik Bilişim Konferansı Bildirileri II. Cilt kitabı içerisinde (s. 895-900). https://ab.org.tr/ab13/kitap/temp/AB13-cilt2-1.pdf

Yenilmez, K., \& Kakmacı, Ö. (2008). İlköğretim yedinci sınıf öğrencilerinin matematikteki hazır bulunuşluk düzeyi. Kastamonu Ĕ̈itim Dergisi, 16(2), 529-542. https://dergipark.org.tr/tr/download/article-file/819025

Yıldırım, S. (2012). Sanal dünya ve web temelli öğrenme ortamlarının öğrencilerin akademik başarıları, motivasyonları ve sosyal bulunuşlukları açısından karşılaştırılması [Yayımlanmamış doktora tezi]. Gazi Üniversitesi. 
Yıldırım, S., \& Şahin, S. (2015). Sanal dünya ve web temelli öğrenme ortamlarının öğrencilerin akademik başarıları ve motivasyonları açısından karşılaştırılması. Erzincan Üniversitesi Eğitim Fakültesi Dergisi, 17(2), 371-402. https://doi.org/10.17556/jef.98976

Yıldız, E. (2016). Çevrimiçi ortamlarda uzaktan eğitim öğrencilerinin topluluk hissi, akademik başarl ve katılımları arasındaki ilişkinin incelenmesi [Yayımlanmamış yüksek lisans tezi]. Ondokuz Mayıs Üniversitesi.

Yurdakul, B. (2005). Uzaktan eğitim - eğitimde yeni yönelimler. Pegem A Yayınları.

Yurdugül, H., \& Alsancak Sırakaya, D. (2013). Çevrimiçi öğrenme hazır bulunuşluluk ölçeği: Geçerlik ve güvenirlik çalışması. Eğitim ve Bilim, 38(169), 391-406. http://egitimvebilim.ted.org.tr/index.php/EB/article/view/2420/521

Yurdugül, H., \& Demir, Ö. (2017). Öğretmen yetiştiren lisans programlarındaki öğretmen adaylarının e-öğrenmeye hazır bulunuşluklarının incelenmesi: Hacettepe üniversitesi örneği. Hacettepe Üniversitesi Eğitim Fakültesi Dergisi, 32(4), 896-915. https://doi.org/10.16986/HUJE.2016022763

Yükseköğretim Kurulu [YÖK] (2020). Basın açıklaması (26.03.2020). https://www.yok.gov.tr/Sayfalar/Haberler/2020/YKS\%20Ertelenmesi\%20Bas\%C4\%B1n\% 20A\%C3\%A7\%C4\%B1klamas\%C4\%B1.aspx 